\title{
Copper(II) Mediated Anion Dependent Formation of Schiff Base Complexes $^{\dagger}$
}

\author{
Sachindranath Pal, ${ }^{\ddagger}$ Anil Kumar Barik, ${ }^{\S}$ Samik Gupta," Arijit Hazra," Susanta Kumar Kar,, ,l \\ Shie-Ming Peng, ${ }^{\perp}$ Gene-Hsiang Lee, ${ }^{\perp}$ Ray J. Butcher, ${ }^{\mathbb{T}}$ M. Salah El Fallah, ${ }^{*, \oplus}$ and Joan Ribas ${ }^{\oplus}$
}

Department of Chemistry, SreeChaitanya College, Habra, North 24 Parganas, West Bengal, India, Department of Chemistry, St. Paul's C.M. College, 33/1, Raja Rammohan Roy Sarani, Calcutta 700 009, India, Department of Chemistry, University College of Science, 92 A.P.C. Road, Calcutta 700 009, India, Department of Chemistry, National Taiwan University, Taipei, Taiwan, 106 Republic of China, Department of Chemistry, Howard University, 2400 Sixth Street, N.W., Washington, DC 20059, and Departament de Química Inorgànica, Facultat de Química, Universitat de Barcelona, Martí i Franquès, 1-11, E-08028 Barcelona, Spain

Received January 28, 2005

\begin{abstract}
A tetranuclear mixed ligand copper(II) complex of a pyrazole containing Schiff base and a hydroxyhexahydropyrimidylpyrazole and copper(II) and nickel(II) complexes of the Schiff base having $\mathrm{N}$-donor atoms have been investigated. A 2 equiv amount of 5-methyl-3-formylpyrazole (MPA) and 2 equiv of 1,3-diamino-2-propanol (1,3$\mathrm{DAP}$ ) on reaction with 1 equiv of copper(II) nitrate produce an unusual tetranuclear mixed ligand complex $\left[\mathrm{Cu}_{4}{ }^{-}\right.$ $\left.\left(\mathrm{L}_{1}\right)_{2}\left(\mathrm{~L}_{2}\right)_{2}\left(\mathrm{NO}_{3}\right)_{2}\right]$ (1), where $\mathrm{H}_{2} \mathrm{~L}_{1}=1$,3-bis(5-methyl-3-formylpyrazolylmethinimino)propane-2-ol and $\mathrm{HL}_{2}=5$-methyl3-(5-hydroxyhexahydro-2-pyrimidyl)pyrazole. In contrast, a similar reaction with nickel(II) nitrate leads to the formation of a hygroscopic intractable material. On the other hand, the reaction involving 2 equiv of MPA and 1 equiv each of 1,3-DAP and various copper(II) salts gives rise to two types of products, viz. [Cu(T3-porphyrinogen) $\left.\left(\mathrm{H}_{2} \mathrm{O}\right)\right] \mathrm{X}_{2}(\mathrm{X}$ $\left.=\mathrm{ClO}_{4}, \mathrm{NO}_{3}, \mathrm{BF}_{4}(2)\right)\left(\mathrm{T}_{3}\right.$-porphyrinogen = 1,6,11,16- tetraza-5,10,15,20- tetrahydroxy-2,7,12,17-tetramethylporphyrinogen) and $\left[\mathrm{Cu}\left(\mathrm{H}_{2} \mathrm{~L}_{1}\right) \mathrm{X}\right] \mathrm{X} \cdot \mathrm{H}_{2} \mathrm{O}(\mathrm{X}=\mathrm{Cl}(3), \mathrm{Br}(4))$. The same reaction carried out with nickel(II) salts also produces two types of compounds $\left[\mathrm{Ni}\left(\mathrm{H}_{2} \mathrm{~L}_{1}\right)\left(\mathrm{H}_{2} \mathrm{O}\right)_{2}\right] \mathrm{X}_{2}\left[\mathrm{X}=\mathrm{ClO}_{4}(\mathbf{5}), \mathrm{NO}_{3}(\mathbf{6}), \mathrm{BF}_{4}(\mathbf{7})\right]$ and $\left[\mathrm{Ni}\left(\mathrm{H}_{2} \mathrm{~L}_{1}\right) \mathrm{X}_{2}\right] \cdot \mathrm{H}_{2} \mathrm{O}[\mathrm{X}=$ $\mathrm{Cl}(8), \mathrm{Br}(9)]$. Among the above species 1,3 , and 5 are crystallographically characterized. In 1 , all four copper atoms are in distorted square pyramidal geometry with $\mathrm{N}_{4} \mathrm{O}$ chromophore around two terminal copper atoms and $\mathrm{N}_{5}$ chromophore around two inner copper atoms. In 3 , the copper atom is also in distorted square pyramidal geometry with $\mathrm{N}_{4} \mathrm{Cl}$ chromophore. The nickel atom in $\mathbf{5}$ is in a distorted octahedral geometry with $\mathrm{N}_{4} \mathrm{O}_{2}$ chromophore, where the metal atom is slightly pulled toward one of the axial coordinated water molecules. Variable-temperature ( 300 to $2 \mathrm{~K}$ ) magnetic susceptibility measurements have been carried out for complex 1 . The separations between the metal centers, viz., $\mathrm{Cu}(1) \cdots \mathrm{Cu}(2), \mathrm{Cu}(2) \cdots \mathrm{Cu}(2 \mathrm{~A})$, and $\mathrm{Cu}(2 \mathrm{~A}) \cdots \mathrm{Cu}(1 \mathrm{~A})$ are $3.858,3.89$, and $3.858 \AA$, respectively. The overall magnetic behavior is consistent with strong antiferromagnetic interactions between the spin centers. The exchange coupling constants between $\mathrm{Cu}(1) \cdots \mathrm{Cu}(2)$ and $\mathrm{Cu}(2) \cdots \mathrm{Cu}(2 \mathrm{~A})$ centers have turned out to be -305.3 and $-400.7 \mathrm{~cm}^{-1}$, respectively, resulting in a $S=1 / 2$ ground state. The complexes are further characterized by UV-vis, IR, electron paramagnetic resonance, and electrochemical studies.
\end{abstract}

\section{Introduction}

Current interest in developing the chemistry of multinuclear transition metal complexes draws inspiration from

\footnotetext{
* To whom correspondence should be addressed.

$\doteqdot$ Dedicated to the late Prof. Nityananda Saha.

SreeChaitanya College.

$\S$ St. Paul's C.M. College.

"University College of Science.

${ }^{\perp}$ National Taiwan University.

II Howard University.

${ }^{\oplus}$ Universitat de Barcelona.
}

3880 Inorganic Chemistry, Vol. 44, No. 11, 2005 two disparate fields such as chemistry of materials and bioinorganic chemistry. ${ }^{1}$ In particular, multinuclear copper(II) complexes have been receiving considerable attention, much of which stems from magnetostructural correlations. The flexibility of the coordination sphere around copper(II), in combination with steric and crystal packing forces, leads to structural diversity. ${ }^{2}$ The growing awareness of the involvement of cluster compounds at the active sites of biomolecules is another point for interest in multinuclear 10.1021/ic0501420 CCC: $\$ 30.25$ C 2005 American Chemical Society Published on Web 05/11/2005 
copper(II) complexes. ${ }^{3,4}$ Tetranuclear copper(II) centers are the focal point of attraction to magneto chemists as these complexes offer opportunities to test magnetic exchange models on more complicated systems. ${ }^{5}$

In the present study, attempts have been made to prepare copper(II) and nickel(II) complexes of the Schiff base ligand $\mathrm{H}_{2} \mathrm{~L}_{1}$ [2:1 condensation product of MPA (5-methyl-3formylpyrazole) and 1,3-DAP (1,3-diamino-2-propanol)] and HL (1:1 condensation product of MPA and 1,3-DAP), using metal ion based template condensation reactions. Surprisingly, when 2 equiv each of MPA and 1,3-DAP are condensed in the presence of 1 equiv of copper(II) nitrate, a pyrazole-bridged tetranuclear mixed ligand complex $\left[\mathrm{Cu}_{4-}\right.$ $\left.\left(\mathrm{L}_{1}\right)_{2}\left(\mathrm{~L}_{2}\right)_{2}\left(\mathrm{NO}_{3}\right)_{2}\right](\mathbf{1})$ is isolated as the sole reaction product. Under similar condition nickel(II) nitrate produces a hygroscopic intractable mass. On the other hand, the reaction between MPA and 1,3-DAP in 2:1 ratio in the presence of copper(II) chloride or bromide and various nickel(II) salts such as perchlorate, nitrate, tetrafluoroborate, chloride, or bromide afford the desired Schiff base complexes of $\mathrm{H}_{2} \mathrm{~L}_{1}$. However, when the same reaction is carried out with the perchlorate, tetrafluoroborate, and nitrate salts of copper, the previously reported $\mathrm{T} 3$-porphyrinogen $[\mathrm{Cu}(\mathrm{T} 3$-porphyrinogen)$\left.\left(\mathrm{H}_{2} \mathrm{O}\right)\right] \mathrm{X}_{2}\left(\mathrm{X}=\mathrm{ClO}_{4}, \mathrm{NO}_{3}, \mathrm{BF}_{4}(\mathbf{2})\right)$ complexes are obtained. ${ }^{6}$ The structure of the ligand $\mathrm{H}_{2} \mathrm{~L}_{1}$ and the plausible mechanism for the cyclization of $\mathrm{HL}$ to $\mathrm{HL}_{2}$ is given in Figure 1. All the observations are depicted in Scheme 1 for clarity, which is outlined in Syntheses discussed later.

\section{Experimental Section}

Materials. 1,3-Diamino-2-propanol was purchased from Aldrich. MPA was synthesized as described earlier. ${ }^{6,7}$ Spectrograde solvents were used for physical measurements. All the other reagents and

(1) (a) Halder, G. J.; Kepert, C. J.; Moubaraki, B.; Murray, K. S.; Cashion, J. D. Science 2002, 298, 1762. (b) Winpenny, R. E. P. J. Chem. Soc., Dalton Trans 2002, 1. (c) Wernsdorfer, W.; Allage-Alcalde, N.; Hendrickson, D. N.; Christou, G. Nature 2002, 416, 406. (d) Bhaduri, S.; Pink, M.; Christou, G. Chem Commun. 2002, 2352. (e) Kruger, P. E.; McKee, V. Chem. Commun. 1999, 639. (f) Holm, R. H.; Kennepohl. P.; Solomon, E. I. Chem. Rev. 1996, 96, 2239. (g) Fentin, D. E. Chem Soc. Rev. 1999, 28, 159.

(2) (a) Trey, I. S. T.; Murthy, N. N.; Weintraub, S. T.; Thompson, L. K.; Karlin, K. D. Inorg. Chem. 1997, 36, 956. (b) Kolks, G.; Lippard, S. J.; Waszczak, J. V.; Lilienthal, H. R. J. Am. Chem. Soc. 1982, 104, 717. (c) Bernhardt, P. V.; and Jones, L. A. Chem. Commun. 1997, 655. (d) Reim, J.; Griesar, K.; Haase, W.; Kreds, B. J. Chem. Soc., Dalton Trans. 1983, 657. (e) Wu, L. P.; Kuroda-Sowa, T.; Maekawa, M.; Suenaga, Y.; Munakata, M. J. Chem. Soc., Dalton Trans. 1996 , 2179. (f) Zhang, H.; Fu, D.; Ji, F.; Wang, G.; Yu, K.; Yao, T. J. Chem Soc., Dalton Trans 1996, 3799.

(3) Karlin, K. D., Tyeklor, Z., Eds. Bioinorganic Chemistry of Copper; Chapman and Hall: New York, 1993.

(4) Jun, L. Q.; True, A. E. Prog. Inorg. Chem. 1990, 38, 97.

(5) (a) Halcrow, M. A.; Sqn, J. S.; Huffman, J. C.; Christou, G. Inorg. Chem. 1995, 34, 4167. (b) Kruger, P. E.; Fallon, G. D.; Moubaraki, B.; Berry, K. J.; Murray K. S. Inorg. Chem. 1995, 34, 4808. (c) Matthews, C. J.; Avery, K.; Xu, Z.; Thompson, L. K.; Zhao, L.; Miller, D. O.; Biradha, K.; Poirer, K.; Zaworotko, M. J.; Wilson, C.; Goeta, A. E.; Howard, J. A. K. Inorg. Chem. 1999, 38, 5266. (d) Atria, A, M.; Vega, A.; Contresas, M.; Valenzula, J.; Spodine, E. Inorg. Chem. 1999, 38, 5681. (e) Kruger, P. E.; Moubariki, B.; Murray, K. S. Polyhedron 1997, 15, 2659. (f) Ruiz, R.; Lloret, F.; Julve, M.; Faus, J.; Munoz, M. C.; Solans, X. Inorg. Chim. Acta 1998, 268, 263.

(6) Paul, S.; Barik, A. K.; Peng, S. M.; Kar, S. K. Inorg. Chem. 2002, 41,5803 , and references therein.

(7) Paul, S.; Barik, A. K.; Butcher, R. J.; Kar, S. K. Polyhedron 2000, 19, 2661.

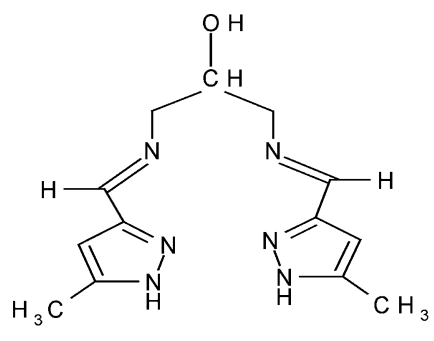

$\mathrm{H}_{2} \mathrm{~L}_{1}$

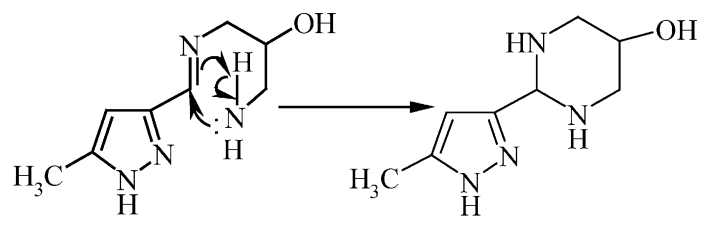

HL

$\mathrm{HL}_{2}$

Figure 1. Structure of the ligands.

solvents were purchased from commercial sources and purified and dried by standard procedure. ${ }^{8}$

Synthesis. Warning! Perchlorate salts are potentially explosive and were handled only in small quantities with care.

Preparation of Complexes. $\left[\mathrm{Cu}_{4}\left(\mathrm{~L}_{1}\right)_{2}\left(\mathrm{~L}_{2}\right)_{2}\left(\mathrm{NO}_{3}\right)_{2}\right]$ (1). A mixture of 1,3-DAP $(0.09 \mathrm{~g}, 1 \mathrm{mmol})$ and MPA $(0.11 \mathrm{~g}, 1 \mathrm{mmol})$ and $\mathrm{Cu}\left(\mathrm{NO}_{3}\right)_{2} \cdot 6 \mathrm{H}_{2} \mathrm{O}(0.148 \mathrm{~g}, 0.5 \mathrm{mmol})$ was refluxed in $50 \mathrm{~mL}$ of $\mathrm{MeOH}$ for $3 \mathrm{~h}$. The resulting green solution was cooled to room temperature (RT) and filtered. The filtrate was concentrated to ca. 10 $\mathrm{mL}$ volume on the water bath temperature and kept for an overnight period to get a green microcrystalline solid (yield $\sim 60 \%$ ). The solid was dried over fused $\mathrm{CaCl}_{2}$ in a desiccator. The compound is soluble in $\mathrm{MeOH}$, EtOH, and dimethylformamide (DMF) but insoluble in $\mathrm{CH}_{2} \mathrm{Cl}_{2}$ and $\mathrm{CH}_{3} \mathrm{CN}$. X-ray-quality crystals of $\left[\mathrm{Cu}_{4}\right.$ $\left.\left(\mathrm{L}_{1}\right)_{2}\left(\mathrm{~L}_{2}\right)_{2}\left(\mathrm{NO}_{3}\right)_{2}\right]$ were grown by slow diffusion of $n$-hexane into an ethanol-dichloromethane $(1: 1(\mathrm{v} / \mathrm{v})$, mixture $)$ solution of the compound. Anal. Calcd for $\mathrm{C}_{21} \mathrm{H}_{29} \mathrm{Cu}_{2} \mathrm{~N}_{11} \mathrm{O}_{5}$ (1): C, 39.25; H, 4.51; N, 23.98. Found: C, 40.19; H, 4.39; N, 23.33. IR $\left(\mathrm{KBr} ; \mathrm{cm}^{-1}\right)$ : 3409, $2922\left(v_{\mathrm{OH}}, v_{\mathrm{NH}}\right), 1618\left(v_{\mathrm{C}=\mathrm{Niminyl}}\right), 1522\left(v_{\mathrm{C}=\mathrm{NPz}}\right), 1396(\mathrm{br}$, $\left.\nu_{\mathrm{NO}_{3}}{ }^{-}\right), 1045\left(\nu_{\mathrm{N}-\mathrm{NPz}}\right)$. DRS $\left(\lambda_{\max }, \mathrm{nm}\right): 614(\mathrm{br}) . \mathrm{UV}-\mathrm{vis}(\mathrm{DMF}$, $\left.\lambda_{\max }, \mathrm{nm}\left(\epsilon, \mathrm{L} \mathrm{M}^{-1} \mathrm{~cm}^{-1}\right)\right): 616$ (173). Molar conductivity $(\mathrm{MeOH}$ solution): $\Lambda_{\mathrm{M}}=80 \Omega^{-1} \mathrm{~cm}^{2} \mathrm{~mol}^{-1}$.

$\left[\mathrm{Cu}\left(\mathrm{T}_{3}\right.\right.$-porphyrinogen $\left.)\left(\mathrm{H}_{2} \mathrm{O}\right)\right] \mathrm{X}_{2}\left(\mathrm{X}=\mathrm{ClO}_{4}(2), \mathrm{NO}_{3}, \mathrm{BF}_{4}\right)$ and $\left[\mathrm{Cu}\left(\mathrm{H}_{2} \mathrm{~L}_{1}\right) \mathrm{X}\right] \mathbf{X} \cdot \mathrm{H}_{2} \mathrm{O}(\mathrm{X}=\mathrm{Cl}(3), \mathrm{Br}(4))$. A mixture of MPA (0.22 g, $2 \mathrm{mmol})$ and 1,3-DAP (0.09 g, $1 \mathrm{mmol})$ in $\mathrm{MeOH}(25$ $\mathrm{mL}$ ) was refluxed for $4 \mathrm{~h}$. Then the light yellow solution was cooled and filtered. To the filtrate, the corresponding $\mathrm{Cu}$ (II) salt (1 mmol) was added and again refluxed for $2 \mathrm{~h}$. Upon slow evaporation of the deep green colored solution at room temperature two different colored complexes were isolated. When the anions are $\mathrm{ClO}_{4}, \mathrm{BF}_{4}$, and $\mathrm{NO}_{3}$, the major complexes are violet, but when anions are $\mathrm{Cl}$ and $\mathrm{Br}$, the complexes are green. The yield of the violet complexes is $40-45 \%$ and the same for the green $70 \%$. The complexes so isolated were dried over fused $\mathrm{CaCl}_{2}$ in a desiccator. X-ray-quality crystals of $\left[\mathrm{Cu}\left(\mathrm{H}_{2} \mathrm{~L}_{1}\right) \mathrm{Cl}\right] \mathrm{Cl} \cdot \mathrm{H}_{2} \mathrm{O}$ were grown by the slow diffusion of benzene into acetonitrile solution of the complex. Anal. Calcd for $\mathrm{C}_{13} \mathrm{H}_{20} \mathrm{CuN}_{6} \mathrm{Cl}_{2} \mathrm{O}_{2}(3)$ : C, 36.57; H, 4.68; N, 19.69. Found: C, 36.68; H, 1.51; N, 20.81. IR (KBr; cm $\left.{ }^{-1}\right): 3377,3130,3010,2901$ $\left(v_{\mathrm{OH}}, \nu_{\mathrm{H}_{2} \mathrm{O}}(\right.$ uncoordinated $\left.), v_{\mathrm{NH}}\right), 1638\left(v_{\mathrm{C}=\mathrm{N}(\text { iminyl })}\right), 1578\left(\mathrm{~ms}, v_{\mathrm{C}=}\right.$ NPz $), 1051\left(\nu_{\mathrm{N}-\mathrm{NPz}}\right)$. DRS $\left(\lambda_{\max }, \mathrm{nm}\right): 714(\mathrm{br})$. UV-vis (DMF, $\left.\lambda_{\max }, \mathrm{nm}\left(\epsilon, \mathrm{L} \mathrm{M}^{-1} \mathrm{~cm}^{-1}\right)\right)$ : 684 (29.0). Molar conductivity (MeOH

(8) Perrin, D. D.; Armarigo, W. L. F.; Perrin, D. R. Purification of Laboratory Chemicals, 2nd ed.; Pergamon: Oxford, England, 1980. 
Pal et al.

Scheme 1

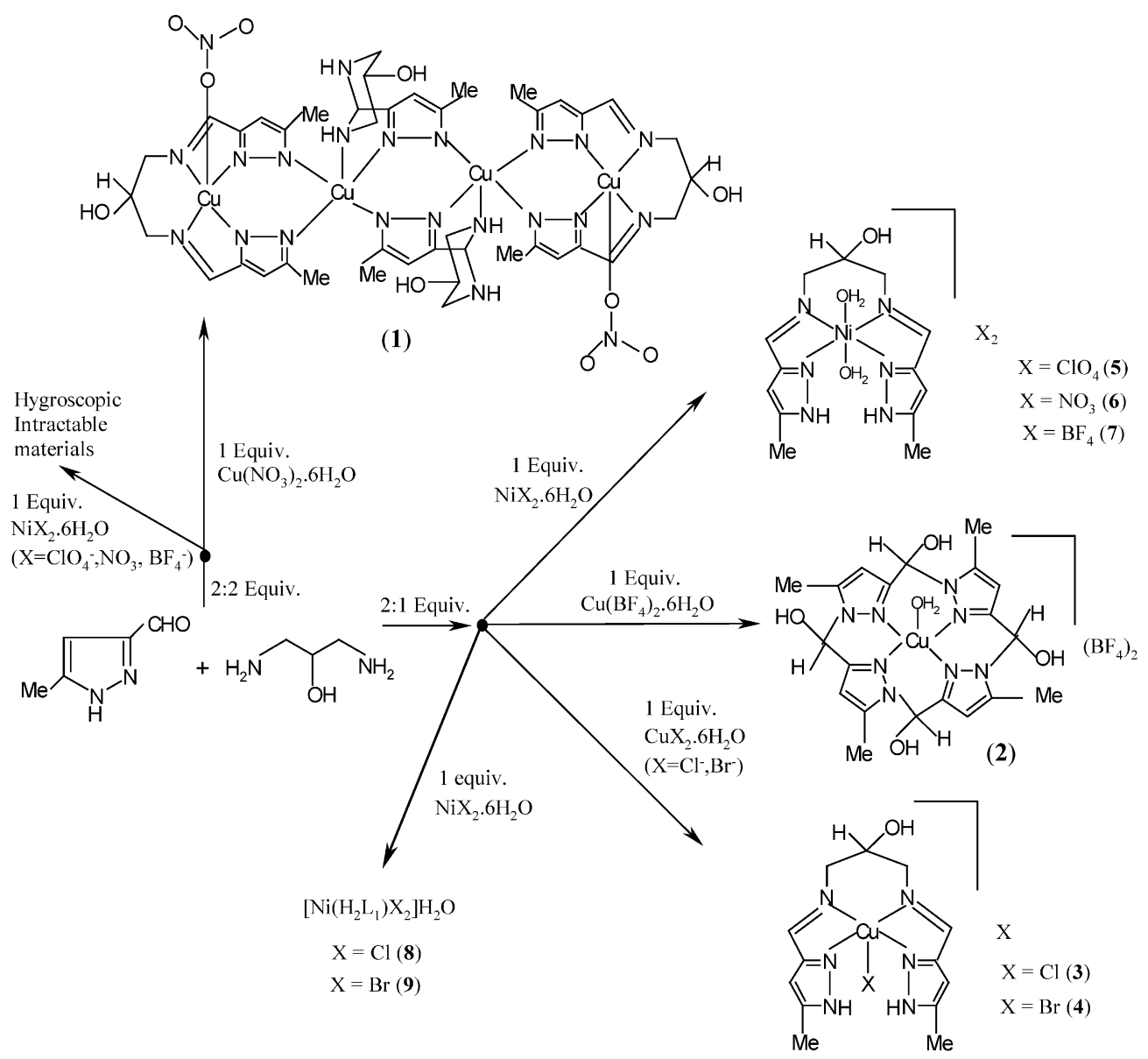

solution): $\Lambda_{\mathrm{M}}=118 \Omega^{-1} \mathrm{~cm}^{2} \mathrm{~mol}^{-1}$. Magnetism (solid state, room temperature): $\mu_{\mathrm{eff}}=1.72 \mu \mathrm{B}$. EPR (at RT polycrystalline state): $g_{\|}=2.289, A_{\|}=213.6 \mathrm{G}, g_{\perp}=2.10, G=2.89, g_{\mathrm{av}}=2.163$. $\left(\mathrm{EtOH}-\mathrm{CH}_{3} \mathrm{OH}\right.$ glass, $\left.77 \mathrm{~K}\right): g_{\|}=2.15, A_{\|}=146 \mathrm{G}, g_{\perp}=2.05$, $G=2.8, g_{\text {av }}=2$ 2.08. Anal. Calcd for $\mathrm{C}_{13} \mathrm{H}_{20} \mathrm{Br}_{2} \mathrm{CuN}_{6} \mathrm{O}_{3}(4): C$, 30.26; H, 3.88; N, 16.29. Found: C, 30.4; H, 3.75; N, 16.80. IR $\left(\mathrm{KBr} ; \mathrm{cm}^{-1}\right): 3435$ (b), 3050, $2924\left(v_{\mathrm{OH}}, v_{\mathrm{H}_{2} \mathrm{O}}\right.$ (uncoordinated), $\left.v_{\mathrm{NH}}\right)$, $1634\left(\mathrm{vs}, v_{\mathrm{C}=\mathrm{N}(\mathrm{iminyl})}\right), 1574\left(v_{\mathrm{C}=\mathrm{NPz}}\right), 1047\left(v_{\mathrm{N}-\mathrm{NPz}}\right)$. DRS $\left(\lambda_{\max }\right.$, $\mathrm{nm}): 734$ (br). UV-vis (DMF, $\left.\lambda_{\max }, \mathrm{nm}\left(\epsilon, \mathrm{L} \mathrm{M}^{-1} \mathrm{~cm}^{-1}\right)\right): 693$ (122). Molar conductivity (MeOH solution): $\Lambda_{\mathrm{M}}=124 \Omega^{-1} \mathrm{~cm}^{2}$ $\mathrm{mol}^{-1}$. EPR (at RT polycrystalline state): $g_{\|}=2.314, A_{\|}=213.4$ $\mathrm{G}, g_{\perp}=2.14, G=2.24, g_{\text {av }}=2.231$.

$\left[\mathrm{Ni}\left(\mathrm{H}_{2} \mathrm{~L}_{1}\right)\left(\mathrm{H}_{2} \mathrm{O}\right)_{2}\right] \mathrm{X}_{2}\left(\mathrm{X}=\mathrm{ClO}_{4}(5), \mathrm{NO}_{3}(6), \mathrm{BF}_{4}(7)\right)$ and [Ni$\left.\left(\mathbf{H}_{2} \mathbf{L}_{1}\right) \mathbf{X}_{2}\right](\mathbf{X}=\mathbf{C l}(\mathbf{8}), \mathbf{B r}(\mathbf{9}))$. A mixture of MPA (0.22 g, 2 mmol) and 1,3-DAP (0.09 g, $1 \mathrm{mmol})$ was refluxed for $4-5 \mathrm{~h}$ in ethanol. To the filtrate, ethanolic solution of $\mathrm{NiX}_{2} \cdot 6 \mathrm{H}_{2} \mathrm{O}(1 \mathrm{mmol})$ was added and refluxed for $3 \mathrm{~h}$. The resulting light pink solution for $\left(\mathrm{X}=\mathrm{ClO}_{4}, \mathrm{NO}_{3}, \mathrm{BF}_{4}\right)$ and light green solution for $(\mathrm{X}=\mathrm{Cl}$, $\mathrm{Br}$ ) upon slow evaporation at room temperature afforded light reddish violet and light green colored amorphous solids, respectively. These were collected and dried over fused $\mathrm{CaCl}_{2}$. The X-rayquality crystals of $\left[\mathrm{Ni}\left(\mathrm{H}_{2} \mathrm{~L}_{1}\right)\left(\mathrm{H}_{2} \mathrm{O}\right)_{2}\right]\left(\mathrm{ClO}_{4}\right)_{2} \cdot 0.5 \mathrm{C}_{6} \mathrm{H}_{6}$ were grown by slow diffusion of benzene into acetonitrile solution of the complex. All attempts to have X-ray quality of $\mathbf{8}$ and $\mathbf{9}$ were in vain. Anal. Calcd for $\mathrm{C}_{13} \mathrm{H}_{22} \mathrm{~N}_{6} \mathrm{Cl}_{2} \mathrm{NiO}_{11}$ (5): C, 27.47; $\mathrm{H}, 3.87$; N, 14.79. Found: C, 27.78; H, 3.92; N, 14.93. IR $\left(\mathrm{KBr}, \mathrm{cm}^{-1}\right)$ : $3370,3189,2930\left(v_{\mathrm{H}_{2} \mathrm{O}}, v_{\mathrm{OH}}, v_{\mathrm{NH}}\right), 1642\left(\mathrm{~s}, v_{\mathrm{C}=\mathrm{N}(\text { iminyl })}\right), 1580(\mathrm{~ms}$, $\left.\nu_{\mathrm{C}=\mathrm{NPz}}\right), 1046\left(\nu_{\mathrm{N}-\mathrm{NPz}}\right)$. DRS $\left(\lambda_{\max }, \mathrm{nm}\right): 359,742$ and $784,1033$. $\mathrm{UV}-\mathrm{vis}\left(\mathrm{MeOH}, \lambda_{\max }, \mathrm{nm}\left(\epsilon, \mathrm{L} \mathrm{M}^{-1} \mathrm{~cm}^{-1}\right)\right)$ : 743 (8.5), 1016 (6.44). Molar conductivity (MeOH): $\Lambda_{\mathrm{M}}=175 \Omega^{-1} \mathrm{~cm}^{2} \mathrm{~mol}^{-1}$. Magnetism (solid state, room temperature): $\mu_{\text {eff }}=3.2 \mu \mathrm{B}$.
Anal. Calcd for $\mathrm{C}_{13} \mathrm{H}_{22} \mathrm{NiN}_{8} \mathrm{O}_{9}(6)$ : C, 31.66; H, 4.46; N, 22.73 Found: C, 31.51; H, 4.58; N, 22.39. IR $\left(\mathrm{KBr} ; \mathrm{cm}^{-1}\right)$ : 3309 (b), $3177,3135,2982\left(v_{\mathrm{OH}}, v_{\mathrm{H}_{2} \mathrm{O}}\right.$ (coordinated), $\left.v_{\mathrm{NH}}\right), 1642\left(\mathrm{~s}, v_{\mathrm{C}}=\right.$ $\mathrm{N}($ iminyl $), 1578\left(\nu_{\mathrm{C}=\mathrm{NPz}}\right), 1384\left(\nu_{\mathrm{NO}_{3}}\right), 1046\left(\nu_{\mathrm{N}-\mathrm{NPz}}\right)$. DRS $\left(\lambda_{\max }\right.$, $\mathrm{nm}): 362,750$ and 791,1025 . UV-vis $\left(\mathrm{MeOH}, \lambda_{\max }, \mathrm{nm}(\epsilon, \mathrm{L}\right.$ $\left.\left.\mathrm{M}^{-1} \mathrm{~cm}^{-1}\right)\right): 749$ (10.7), 1013 (6.55). Molar conductivity $(\mathrm{MeOH}): \Lambda_{\mathrm{M}}=136 \Omega^{-1} \mathrm{~cm}^{2} \mathrm{~mol}^{-1}$. Magnetism (solid state, room temperature): $\mu_{\text {eff }}=2.85 \mu \mathrm{B}$.

Anal. Calcd for $\mathrm{C}_{13} \mathrm{H}_{22} \mathrm{NiN}_{6} \mathrm{O}_{2} \mathrm{~B}_{2} \mathrm{~F}_{8}$ (7): C, 28.78; H, 4.05; N, 15.5. Found: C, 29.01; H, 4.25; N, 15.81. IR $\left(\mathrm{KBr} ; \mathrm{cm}^{-1}\right)$ : 3355$(\mathrm{vb})\left(v_{\mathrm{OH}}, v_{\mathrm{H}_{2} \mathrm{O}}\right.$ (coordinated), $\left.v_{\mathrm{NH}}\right), 1646\left(\mathrm{~s}, v_{\mathrm{C}=\mathrm{N}(\text { iminyl })}\right), 1582\left(v_{\mathrm{C}}=\right.$ $\mathrm{NPz}), 1046\left(\nu_{\mathrm{N}-\mathrm{NPzmixedwithBF}_{4-}}\right)$. DRS $\left(\lambda_{\max }, \mathrm{nm}\right): 358,747$ and 781 , 1040. UV-vis (DMF, $\left.\lambda_{\max }, \mathrm{nm}\left(\epsilon, \mathrm{L} \mathrm{M}^{-1} \mathrm{~cm}^{-1}\right)\right): 972$ (5.00), 1173 (3.00). Molar conductivity (DMF): $\Lambda_{\mathrm{M}}=167 \Omega^{-1} \mathrm{~cm}^{2} \mathrm{~mol}^{-1}$. Magnetism (solid state, room temperature): $\mu_{\mathrm{eff}}=2.74 \mu \mathrm{B}$.

Anal. Calcd for $\mathrm{C}_{13} \mathrm{H}_{20} \mathrm{NiN}_{4} \mathrm{O}_{2} \mathrm{Cl}_{2}(8)$ : C, 36.99; $\mathrm{H}, 4.74 ; \mathrm{N}$, 19.91. Found: C, 37.14; H, 4.29; N, 19.89. IR $\left(\mathrm{KBr} ; \mathrm{cm}^{-1}\right)$ : 3377 , 3130, 3010, 2901, $2774\left(v_{\mathrm{OH}}, v_{\mathrm{H}_{2} \mathrm{O}}, v \mathrm{NH}\right), 1638$ (vs, $\left.v_{\mathrm{C}=\mathrm{N}(\mathrm{iminyl})}\right)$, $1578\left(\mathrm{~s}, v_{\mathrm{C}=\mathrm{NPz}}\right), 1051\left(v_{\mathrm{N}-\mathrm{NPz}}\right)$. DRS $\left(\lambda_{\max }, \mathrm{nm}\right): 361,783$ and 829, 1163. UV-vis $\left(\mathrm{MeOH}, \lambda_{\max }, \mathrm{nm}\left(\epsilon, \mathrm{L} \mathrm{M}^{-1} \mathrm{~cm}^{-1}\right)\right)$ : 752 (10.0), 1051 (6.05). Molar conductivity $(\mathrm{MeOH}): \Lambda_{\mathrm{M}}=91.6$ (74.1 in DMF) $\Omega^{-1} \mathrm{~cm}^{2} \mathrm{~mol}^{-1}$. Magnetism (solid state, room temperature): $\mu_{\mathrm{eff}}=3.14 \mu \mathrm{B}$.

Anal. Calcd for $\mathrm{C}_{13} \mathrm{H}_{20} \mathrm{NiN}_{4} \mathrm{O}_{2} \mathrm{Br}_{2}$ (9): C, 30.54; H, 3.91; N, 16.44. Found: C, 30.69; H, 3.67; N, 16.41. IR ( $\left.\mathrm{KBr} ; \mathrm{cm}^{-1}\right)$ : 3368, $3170,2940\left(v_{\mathrm{OH}}, v_{\mathrm{H}_{2} \mathrm{O}}, v_{\mathrm{NH}}\right), 1636\left(\mathrm{vs}, v_{\mathrm{C}=\mathrm{N}(\mathrm{iminyl})}\right), 1575\left(\mathrm{~s}, v_{\mathrm{C}}=\right.$ $\mathrm{NPz}), 1042\left(\nu_{\mathrm{N}-\mathrm{NPz}}\right)$. DRS $\left(\lambda_{\max }, \mathrm{nm}\right): 358,807$ and 852, 1160. UVvis $\left(\mathrm{MeOH}, \lambda_{\max }, \mathrm{nm}\left(\epsilon, \mathrm{L} \mathrm{M}^{-1} \mathrm{~cm}^{-1}\right)\right)$ : 746 (13.1), 1059 (8.7). Molar conductivity $(\mathrm{MeOH}): \Lambda_{\mathrm{M}}=84.9$ (68.3 in DMF) $\Omega^{-1} \mathrm{~cm}^{2}$ $\mathrm{mol}^{-1}$. Magnetism (solid state, room temperature): $\mu_{\mathrm{eff}}=3.07 \mu \mathrm{B}$.

Physical Methods. ${ }^{1} \mathrm{H}$ NMR spectra were recorded with a Bruker 
Table 1. Crystal Data, Data Collection, and Structure Refinement for Complex 1, 3, and 5

\begin{tabular}{|c|c|c|c|}
\hline empirical formula & $\mathrm{C}_{21} \mathrm{H}_{26} \mathrm{Cu}_{2} \mathrm{~N}_{11} \mathrm{O}_{5}(\mathbf{1})$ & $\mathrm{C}_{13} \mathrm{H}_{18} \mathrm{Cl}_{2} \mathrm{CuN}_{6} \mathrm{O}_{1.2}(\mathbf{3})$ & $\mathrm{C}_{16} \mathrm{H}_{25} \mathrm{Cl}_{2} \mathrm{~N}_{6} \mathrm{NiO}_{11}(\mathbf{5})$ \\
\hline fw & 639.61 & 411.97 & 607.03 \\
\hline temp, $\mathrm{K}$ & $150(1)$ & $93(2)$ & 295(2) \\
\hline Wavelength, $\AA$ & 0.71073 & 0.71073 & 0.71073 \\
\hline cryst syst & monoclinic & monoclinic & trioclinic \\
\hline space group & $C 2 / c$ & $P 2_{1} / n$ & $P 1$ \\
\hline \multicolumn{4}{|l|}{ unit cell dimens } \\
\hline$a, \AA$ & $24.686(2)$ & $7.525(2)$ & $8.6571(5)$ \\
\hline$b, \AA$ & $17.6204(15)$ & $19.728(6)$ & $10.7433(6)$ \\
\hline$c, \AA$ & $14.8725(13)$ & $11.971(4)$ & $14.0972(8)$ \\
\hline$\alpha, \operatorname{deg}$ & 90 & 90 & $79.281(1)$ \\
\hline$\beta, \operatorname{deg}$ & $96.205(2)$ & $105.121(5)$ & $80.511(1)$ \\
\hline$\gamma, \mathrm{deg}$ & 90 & 90 & $76.557(1)$ \\
\hline vol, $\AA^{3}$ & $6431.2(10)$ & $1715.5(9)$ & $1242.76(12)$ \\
\hline $\mathrm{Z}$ & 8 & 4 & 2 \\
\hline density (calcd), $\mathrm{mg} / \mathrm{m}^{3}$ & 1.321 & 1.595 & 1.622 \\
\hline$F(000)$ & 2616 & 842 & 626 \\
\hline reflens collected & 18731 & 13254 & 14154 \\
\hline indepen reflens & $5661\left(R_{\text {int }}=0.0928\right)$ & $4205\left(R_{\mathrm{int}}=0.0449\right)$ & $5683\left(R_{\mathrm{int}}=0.0243\right)$ \\
\hline refinement method & full-matrix least-squares on $F^{2}$ & full-matrix least-squares on $F^{2}$ & full-matrix least-squares on $F^{2}$ \\
\hline goodness-of-fit on $F^{2}$ & 1.087 & 1.075 & 1.038 \\
\hline \multicolumn{4}{|l|}{ final $R$ indices $[I>2 \sigma(I)]$} \\
\hline R1 & 0.0916 & 0.0348 & 0.0594 \\
\hline wR2 & 0.2566 & 0.0863 & 0.1769 \\
\hline \multicolumn{4}{|l|}{$R$ indices (all data) } \\
\hline $\mathrm{R} 1$ & 0.1473 & 0.0412 & 0.0693 \\
\hline wR2 & 0.2946 & 0.0863 & 0.1858 \\
\hline
\end{tabular}

AM300L (300 MHz) superconducting FT-NMR. Infrared spectra were recorded on $\mathrm{KBr}$ disks $\left(400-4000 \mathrm{~cm}^{-1}\right)$ with a Perkin-Elmer FTIR spectrophotometer. UV-vis spectra and DRS were measured on a Hitachi U-3501 spectrophotometer. The EPR spectra of $\mathbf{1}$ have been recorded on an X-band Bruker spectrometer (ESR 300E), working with an Oxford helium liquid cryostat for variable temperature. The room-temperature EPR spectra for $\mathbf{3}$ and $\mathbf{4}$ were obtained using Varian E-112 spectrometer operating at X-band. The field was calibrated with a powder sample of DPPH $(g=2.0037)$. Solvents used were $\mathrm{MeOH}$ with copper complex concentration approximately $10^{-3} \mathrm{M}$. Room-temperature magnetic moments were measured with a vibrating sample magnatometer. Electrical conductivity measurements were carried out in $\mathrm{MeOH} / \mathrm{DMF}$ solution using a Systronics model 304 digital conductivitymeter. Elemental analyses were carried out at IACS, Kolkata; with a Perkin-Elmer model $2400 \mathrm{CHN}$ analyzer. Cyclic voltammetry was carried out using a Sycopel model AEW2 1820F/S instrument. The measurements were performed at $293 \mathrm{~K}$ in $\mathrm{MeOH}$ solutions containing 0.2 M TEAP as supporting electrolyte, respectively, and $10^{-3}-10^{-4}$ $\mathrm{M} \mathrm{Cu}(\mathrm{II})$ complex deoxygenated by bubbling with nitrogen. The working, counter, and reference electrodes used were a platinum wire, a platinum coil, and an SCE. The magnetic susceptibility of powdered sample $\mathbf{1}$ was measured by using a SQUID magnetometer in the temperature range $2-300 \mathrm{~K}$ at an applied field of $0.1 \mathrm{~T}$. The contribution of the sample holder was determined separately in the same temperature range and field. Diamagnetic corrections were estimated from Pascal's constants. The magnetic susceptibility was fitted by least-squares techniques.

X-ray Crystal Structure Analysis. Relevant crystallographic data are summarized in Table 1 . The intensity data for $\mathbf{1}$ and $\mathbf{5}$ were collected on a Bruker SMART APEX CCD diffractometer, and those for $\mathbf{3}$ were done on an Enraf-Nonius CAD4 diffractometer, using graphite monochromated Mo $\operatorname{K} \alpha$ radiation $(\lambda=0.71073 \AA)$ in the $\omega-2 \theta$ scan mode. These were corrected for Lorentzpolarization effects. The structures were solved by using XCAD49, SHELXTL, and the SHELEX-97 packages of programs and refined by full-matrix least -squares technique based on $F^{2}$ (SHELEX-97). Hydrogen atoms were added in the calculated positions.

Syntheses. The coordination compounds of the expected Schiff

Chart 1
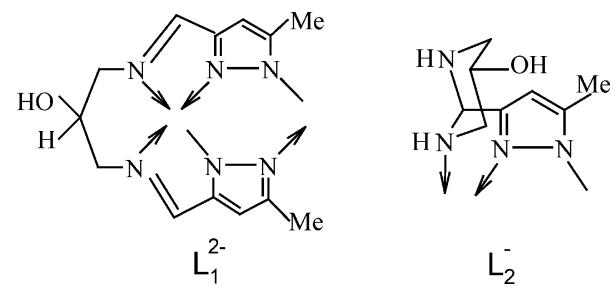

base ligands were synthesized in situ by template methodology in the presence of $\mathrm{Cu}(\mathrm{II})$ and $\mathrm{Ni}$ (II) ions. In mixed ligand tetranuclear $\mathrm{Cu}$ (II) complex the reaction followed an unprecedented path leading to cyclization of mono Schiff base HL to 5-methyl-3-(5-hydroxyhexahydro-2-pyrimidyl) pyrazole $\left(\mathrm{HL}_{2}\right)$. The newly formed cyclic ligand $\left(\mathrm{HL}_{2}\right)$ formation is unique for $\mathrm{Cu}$ (II) only. This intramolecular cyclization is due to the proper orientation of the free amino group (in the condensation product of MPA and 1,3-DAP in 1:1 molar proportion) to the close proximity of the azomethine carbon in HL ligand in such an extent so that it cannot but undergo cyclization. It behaves as an uninegative tridentate bridging one in complex 1. In the case of $\mathrm{Ni}$ (II) only a mononuclear complex is isolated with $\mathrm{H}_{2} \mathrm{~L}_{1}$. In mononuclear $\mathrm{Cu}$ (II) complexes for $\mathrm{ClO}_{4}{ }^{-}$, $\mathrm{NO}_{3}{ }^{-}$, and $\mathrm{BF}_{4}^{-}$anions, the reaction again followed an unprecedented path, leading to porphyrinogen complex involving pyrazole aldehyde moiety as the building blocks. The porphyrinogen formation is reported in our earlier communication. ${ }^{6}$ Here 1,3diamino-2-propanol acts as the base for aldol type of condensation. All the observations and the coordination modes of the ligands are depicted in Scheme 1 and Chart 1, respectively, for clarity.

\section{Results and Discussion}

The Schiff base $\mathrm{H}_{2} \mathrm{~L}_{1}$ acts as tetradentate neutral donor for mononuclear $\mathrm{Cu}(\mathrm{II})$ and $\mathrm{Ni}(\mathrm{II})$ complexes, whereas in tetranuclear $\mathrm{Cu}(\mathrm{II})$ complex it serves as the binegative hexadentate bridging one.

The crystal structures of the $\mathrm{Cu}(\mathrm{II})$ complexes (1 and $\mathbf{3}$ ) and the $\mathrm{Ni}(\mathrm{II})$ (5) complex are described below.

Description of Crystal Structures. (a) Compound 1. A perspective view of the complex is shown in Figure $2 \mathrm{a}$. The 
Pal et al.
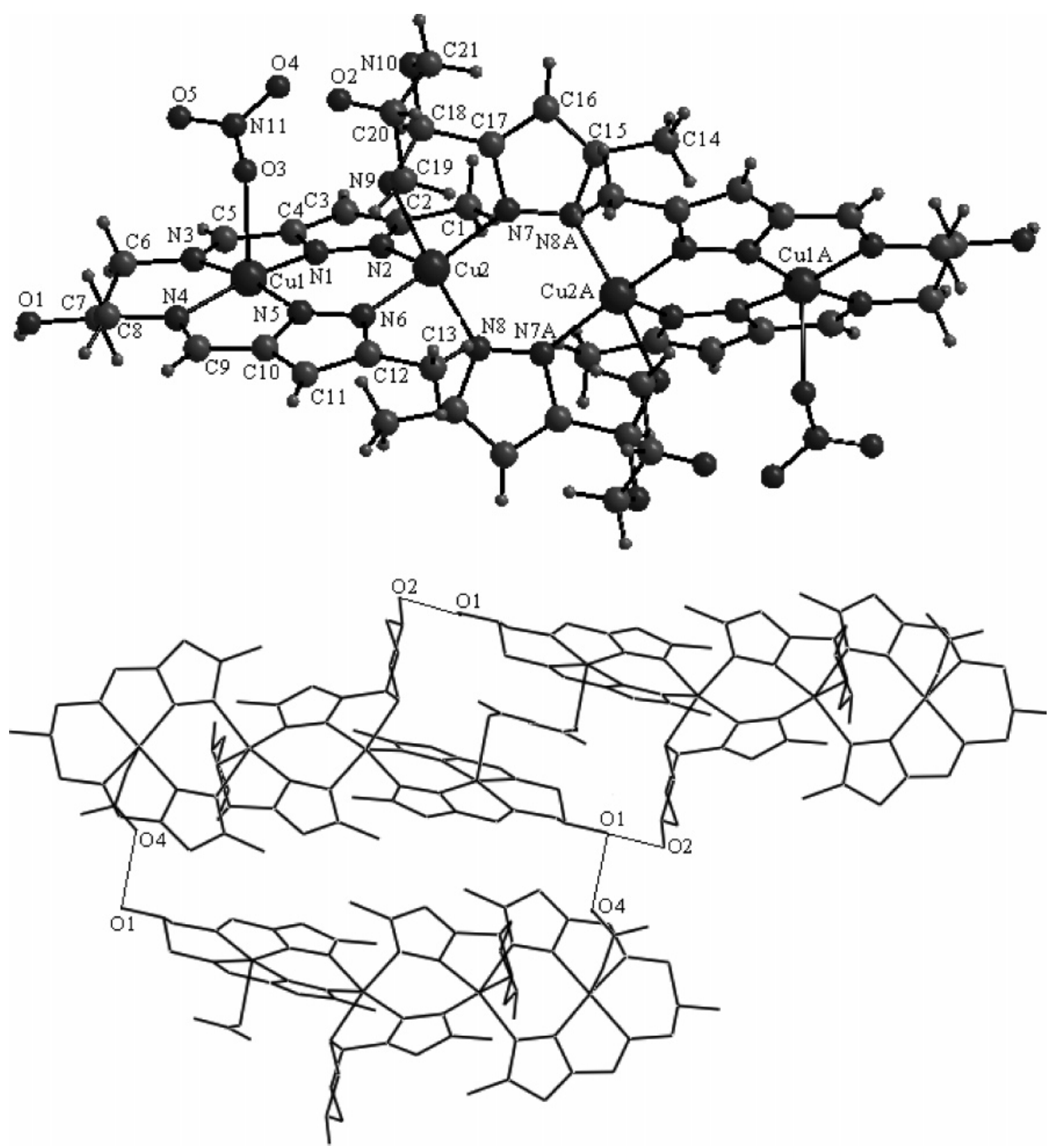

Figure 2. (a) Molecular structure of $\mathbf{1}$. (b) H-bonding mode of $\mathbf{1 .}$

selected metrical parameters are listed in Tables 1 and 2. This is a tetracopper pyrazole bridged mixed ligand complex. In the solid state, the title compound is crystallized in such a way so that only half of the molecule is crystallographically unique. The title compound has two different ligands. The ligands $\mathrm{H}_{2} \mathrm{~L}_{1}$ and $\mathrm{HL}_{2}$ act as binegative and uninegative, respectively. The coordination polyhedra around all the $\mathrm{Cu}$ (II) ions are square-pyramidal. The geometry of terminal $\mathrm{Cu}$ (1) and $\mathrm{Cu}(1 \mathrm{~A})$ are completed by four nitrogen donors $\mathrm{N}(1)$, $\mathrm{N}(3), \mathrm{N}(4)$, and $\mathrm{N}(5)$ (two imine and two pyrazole N-atoms of the same ligand $\mathrm{H}_{2} \mathrm{~L}_{1}$ ) forming the basal plane (mean plane deviation $0.0038 \AA$ ) and one of the oxygen atoms of the nitrate ion is in the apical site. Each terminal copper atom is displaced approximately by $0.1659 \AA$ out of the basal plane toward the apical $\mathrm{O}$ atom. Each of the inner $\mathrm{Cu}(2)$ and $\mathrm{Cu}$ (2A) atoms is also in a distorted square pyramidal geometry in which the basal plane (mean plane deviation, $0.1407 \AA$ ) is defined by the three nitrogen donors $[\mathrm{N}(6), \mathrm{N}(8)$, and $\mathrm{N}(7)]$ of three pyrazole rings and $\mathrm{N}(9)$ pyrimidine ring nitrogen atom of hydroxyhexahydropyrimidylpyrazole in chair form. A nitrogen atom of pyrazole ring of $\mathrm{H}_{2} \mathrm{~L}_{1}$ ligand occupies the apical site. Here each $\mathrm{Cu}$ atom is also shifted $0.3196 \AA$ toward the apical $\mathrm{N}$-atom. The above conclusion is drawn from the $\mathrm{Cu}-\mathrm{N}$ bond distances (Table 2). The dihedral angle between the planes $[\mathrm{Cu}(1), \mathrm{N}(1), \mathrm{N}(2), \mathrm{N}(6), \mathrm{N}(5)$ and $\mathrm{Cu}$ (1A), $\mathrm{N}(1 \mathrm{~A}), \mathrm{N}(2 \mathrm{~A}), \mathrm{N}(6 \mathrm{~A}), \mathrm{N}(5 \mathrm{~A})]$ is $47.554^{\circ}$, which indicates that they are neither parallel nor orthogonal.

$\mathrm{The} \mathrm{Cu}-\mathrm{N}$ bond distances of $\mathrm{Cu}(1)$ are shorter than those of the similar bonds in $\mathrm{Cu}(2)$. In all the complexes the $\mathrm{Cu}-\mathrm{N}$ bond distances (except for the apical one) are shorter than those reported for $\left[\mathrm{Cu}_{4}(\mathrm{dppn})_{4}\right]\left(\mathrm{CF}_{3} \mathrm{SO}_{3}\right)_{4}{ }^{9}$ (where dppn $=$

(9) Youinou, M.-T.; Rahmouni, N.; Fisher J.; Osborn, J. A. Angew. Chem. Int. Ed. Engl. 1992, 31, 733. 
Table 2. Selected Bond Lengths $(\AA)$ and Angles (deg) for 1, 3 and $\mathbf{5}$ with Esds in Parentheses

$\mathrm{Cu}(1)-\mathrm{N}(1)$
$\mathrm{Cu}(1)-\mathrm{N}(5)$
$\mathrm{Cu}(1)-\mathrm{N}(3)$
$\mathrm{Cu}(1)-\mathrm{N}(4)$
$\mathrm{Cu}(1)-\mathrm{O}(3)$
$\mathrm{Cu}(2)-\mathrm{N}(8)$
$\mathrm{Cu}(2)-\mathrm{N}(7)$
$\mathrm{Cu}(2)-\mathrm{N}(6)$
$\mathrm{Cu}(2)-\mathrm{N}(9)$
$\mathrm{Cu}(2)-\mathrm{N}(2)$

$\mathrm{N}(1)-\mathrm{Cu}(1)-\mathrm{N}(5)$

$\mathrm{N}(1)-\mathrm{Cu}(1)-\mathrm{N}(3)$

$\mathrm{N}(5)-\mathrm{Cu}(1)-\mathrm{N}(3)$

$\mathrm{N}(1)-\mathrm{Cu}(1)-\mathrm{N}(4)$

$\mathrm{N}(5)-\mathrm{Cu}(1)-\mathrm{N}(4)$

$\mathrm{N}(3)-\mathrm{Cu}(1)-\mathrm{N}(4)$

$\mathrm{N}(1)-\mathrm{Cu}(1)-\mathrm{O}(3)$

$\mathrm{N}(5)-\mathrm{Cu}(1)-\mathrm{O}(3)$

$\mathrm{N}(3)-\mathrm{Cu}(1)-\mathrm{O}(3)$

$\mathrm{N}(4)-\mathrm{Cu}(1)-\mathrm{O}(3)$

$\mathrm{N}(8)-\mathrm{Cu}(2)-\mathrm{N}(7)$

$\mathrm{N}(8)-\mathrm{Cu}(2)-\mathrm{N}(6)$

$\mathrm{N}(7)-\mathrm{Cu}(2)-\mathrm{N}(6)$

$\mathrm{N}(8)-\mathrm{Cu}(2)-\mathrm{N}(9)$

$\mathrm{N}(7)-\mathrm{Cu}(2)-\mathrm{N}(9)$

$\mathrm{N}(6)-\mathrm{Cu}(2)-\mathrm{N}(9)$

$\mathrm{N}(8)-\mathrm{Cu}(2)-\mathrm{N}(2)$

$\mathrm{N}(7)-\mathrm{Cu}(2)-\mathrm{N}(2)$

$\mathrm{N}(6)-\mathrm{Cu}(2)-\mathrm{N}(2)$

$\mathrm{N}(9)-\mathrm{Cu}(2)-\mathrm{N}(2)$

3, 6-bis(2'-pyridyl)pyridazine), $\left[\mathrm{Cu}_{2}(\operatorname{tren})_{2} \mathrm{CN}\right]\left(\mathrm{ClO}_{4}\right)_{3} \cdot \mathrm{H}_{2} \mathrm{O}{ }^{10}$ (where tren $=$ tris(aminoethyl)amine), $\left.\mathrm{Cu}_{2}\left(\mathrm{~N}_{6} \mathrm{O}\right)(\mathrm{OH})\right]$ $\left(\mathrm{BF}_{4}\right)_{2}{ }^{11}$ (where $\mathrm{N}_{6} \mathrm{OH}=2$,6-bis[[bis[2-(1-pyrazolyl)ethyl)]amino]methyl]-p-cresol), $\left[\mathrm{Cu}\left(\mathrm{Pim}{ }^{i \mathrm{Pr} 2}\right)\right]_{2} \mathrm{CO}_{3}\left(\mathrm{BF}_{4}\right)_{2}{ }^{12}$ (where $\mathrm{Pim}^{\mathrm{ipr} 2}=$ tris[2-(1,4-diisopropylimidazolyl)]phosphine), and comparable with those reported for $\left[\mathrm{Cu}_{2}(\mathrm{bpzbiap}) \mathrm{Cl}_{3}\right]^{13}$ (where bpzbiap $=1,5$-bis(1-pyrazolyl)-3-[bis(2-imidazolyl)methyl $]$ azapentane), $\left[\mathrm{Cu}\left(\mathrm{T}_{3}\right.\right.$-porphyrinogen $\left.)\left(\mathrm{H}_{2} \mathrm{O}\right)\right]\left(\mathrm{NO}_{3}\right)_{2}{ }^{6}$ (where $\mathrm{T}_{3}$-porphyrinogen $=1,6,11,16$-tetraza-5,10,15,20tetrahydroxy-2,7,12,17-tetramethylporphyrinogen), and $[\mathrm{Cu}-$ (II)(Pmea) $\mathrm{Cl}] \mathrm{ClO}_{4} \cdot \mathrm{H}_{2} \mathrm{O}^{14}$ (where Pmea $=$ bis[(2-pyridyl)methyl]-2-(2-pyridyl)ethylamine). In particular, in this complex, the pyrazolate nitrogen to $\mathrm{Cu}(2)$ bond lengths are slightly shorter than the $\mathrm{Cu}$-iminyl nitrogen, $\mathrm{Cu}$-pyrazole nitrogen, and $\mathrm{Cu}$-hexahydrohydroxypyrimidyl nitrogen bonds. The shorter distance may be ascribed to the increased basicity of the pyrazolate moiety.

Two different types of interesting weak intermolecular $\mathrm{H}$-bonding are present in the molecule. One of the nitrate oxygen of one molecule forms H-bond with uncoordinated $-\mathrm{OH}$ of the ligand $\mathrm{H}_{2} \mathrm{~L}_{1}$ of another unit, which in turn forms a $\mathrm{H}$-bond with free $-\mathrm{OH}$ of $\mathrm{HL}_{2}$ of another asymmetric unit.

(10) Fortea, A. R.; Alemany, P.; Alvarez, S.; Ruiz, E.; Scuiller, A.; Decroix, C.; Marvaud, V.; Vaissermann, J.; Vergaguer, M.; Roseman, I.; Julve, M. Inorg. Chem. 2001, 40, 5868.

(11) Sorrel, T. N.; Jameson, D. L.; O'Connor, C. J. Inorg. Chem. 1984, 23, 190.

(12) Sorrell, T. N.; Allen, W. E.; White, P. S. Inorg. Chem. 1995, 34, 952.

(13) Tabbi, G.; Driessen, W. L.; Redijk, J.; Bonomo, R. P.; Veldman, N.; Spek, A. L. Inorg. Chem. 1997, 36, 1168.

(14) Schatz, M.; Becker, M.; Thaler, F.; Hampel, F.; Schindler, S.; Jacobson, R. R.; Tyekler, Z.; Murthy, N. V.; Ghosh, P.; Chen, Q.; Zubieta, J.; Karlin, K. D. Inorg. Chem. 2001, 41, 2312.

$\begin{array}{lll}1.9986(18) & \mathrm{Ni}-\mathrm{N}(3) & 2.060(3) \\ 2.0127(17) & \mathrm{Ni}-\mathrm{N}(4) & 2.069(3) \\ 2.0255(17) & \mathrm{Ni}-\mathrm{N}(2) & 2.076(3) \\ 2.0308(18) & \mathrm{Ni}-\mathrm{N}(5) & 2.082(3) \\ 2.4199(8) & \mathrm{Ni}-\mathrm{O}(3) & 2.087(3) \\ & \mathrm{Ni}-\mathrm{O}(2) & 2.117(3)\end{array}$

$\mathrm{N}(3)-\mathrm{Ni}-\mathrm{N}(4) \quad 92.12(13)$

$\mathrm{N}(3)-\mathrm{Ni}-\mathrm{N}(2) \quad 78.79(13)$

$\mathrm{N}(4)-\mathrm{Ni}-\mathrm{N}(2) \quad 170.90(12)$

$\mathrm{N}(3)-\mathrm{Ni}-\mathrm{N}(5) \quad 171.09(13)$

$\mathrm{N}(4)-\mathrm{Ni}-\mathrm{N}(5) \quad 79.05(12)$

$\mathrm{N}(2)-\mathrm{Ni}-\mathrm{N}(5) \quad 110.05(12)$

$\mathrm{N}(3)-\mathrm{Ni}-\mathrm{O}(3) \quad 88.61(14)$

$\mathrm{N}(4)-\mathrm{Ni}-\mathrm{O}(3) \quad 90.33(14)$

$\mathrm{N}(2)-\mathrm{Ni}-\mathrm{O}(3) \quad 89.07(14)$

$\mathrm{N}(5)-\mathrm{Ni}-\mathrm{O}(3) \quad 92.61(14)$

$\mathrm{N}(3)-\mathrm{Ni}-\mathrm{O}(2) \quad 92.59(13)$

$\mathrm{N}(4)-\mathrm{Ni}-\mathrm{O}(2) \quad 92.85(12)$

$\mathrm{N}(2)-\mathrm{Ni}-\mathrm{O}(2) \quad 87.83(12)$

$\mathrm{N}(5)-\mathrm{Ni}-\mathrm{O}(2) \quad 87.69(13)$

$\mathrm{O}(3)-\mathrm{Ni}-\mathrm{O}(2) \quad 176.79(13)$

(b) Compound 3. A perspective view of the cationic portion of the complex is represented in Figure 3. Selected bond distances and bond angles are listed in Tables 1 and 2 . The copper(II) ion is in a distorted square pyramidal environment. Four short in-plane bonds $(1.99-2.03 \AA)$ are formed with the nitrogen atoms $\mathrm{N}(1 \mathrm{~B}), \mathrm{N}(2 \mathrm{~B}), \mathrm{N}(2 \mathrm{~A})$, and $\mathrm{N}(1 \mathrm{~A})$ of the tetradentate ligand $\mathrm{H}_{2} \mathrm{~L}_{1}$. The apical position is occupied by one chloride ion with a longer bond (2.419 $\AA$ ), and the $\mathrm{Cu}$ atom is displaced by $0.0321 \AA$ out of the least-squares basal plane. The shorter trans bond angles $\mathrm{N}(1 \mathrm{~B})-\mathrm{Cu}-\mathrm{N}(2 \mathrm{~A})=157.50^{\circ}$ and $\mathrm{N}(2 \mathrm{~B})-\mathrm{Cu}-\mathrm{N}(1 \mathrm{~A})=$ $160.94^{\circ}$ suggest considerable distortion of a square plane formed by $\mathrm{N}$-atoms. These bond distances and angles are comparable with those reported for $\left[\mathrm{Cu}(\mathrm{BIPO})\left(\mathrm{ClO}_{4}\right)\right]\left(\mathrm{NO}_{3}\right)$. $2 \mathrm{H}_{2} \mathrm{O}^{15}$ (where $\mathrm{BIPO}=1,3$-bis[(4-methyl-5-imidazol-1-yl)ethylideneamino]propan-2-ol), $\left[\mathrm{Cu}(\mathrm{L})\left(\mathrm{NO}_{3}\right)\right] \mathrm{Cl}^{16}$ (where $\mathrm{L}$ $=N, N^{\prime}$-bis(pyrazol-3-ylmethyl)-1,2-ethanediamine), $\{[\mathrm{Cu}$ (appn) $\left.]\left(\mathrm{ClO}_{4}\right)_{2}\right\}_{2} \cdot \mathrm{H}_{2} \mathrm{O}{ }^{17}$ (where appn $=N, N^{\prime}$-propylenebis(2-actoylpyrimidineiminato), $\left[\mathrm{Cu}\left(2-\mathrm{Me} \mathrm{Im}_{2} \mathrm{PrO}\right) \mathrm{H}_{2} \mathrm{O}\right] \cdot 2 \mathrm{ClO}_{4}{ }^{18}$ (where $2-\mathrm{MeIm}_{2} \mathrm{PrO}=1,3$-bis $(N$-methylimidazolimine)propan-2-ol).

The counterion, chloride, is hydrogen bonded to both pyrazole $\mathrm{N}-\mathrm{H}$ groups of the complex cation. The alcoholic $\mathrm{OH}$ group $[\mathrm{O}(10)]$ atom of the ligand remains uncoordinated to the copper ion, and it undergoes a weak H-bonding interaction with coordinated chloride ion of another molecule

(15) Long, L.-S.; Tong, Y.-X.; Yang, S.-P.; Chen, X.-M.; Ji, L.-N. Trans. Met. Chem. 1999, 24, 440.

(16) Deters, R.; Krmer, R. Inorg. Chim. Acta 1998, 269, 117.

(17) Liu, C.-M.; Xiong, R.-G.; You, X.-Z. Polyhedron 1997, 16, 119.

(18) Doman, T. N.; Richardson, J. F.; Arar, L.; Buchanan, R. M. Inorg. Chim. Acta 1989, 159, 219. 
Pal et al.

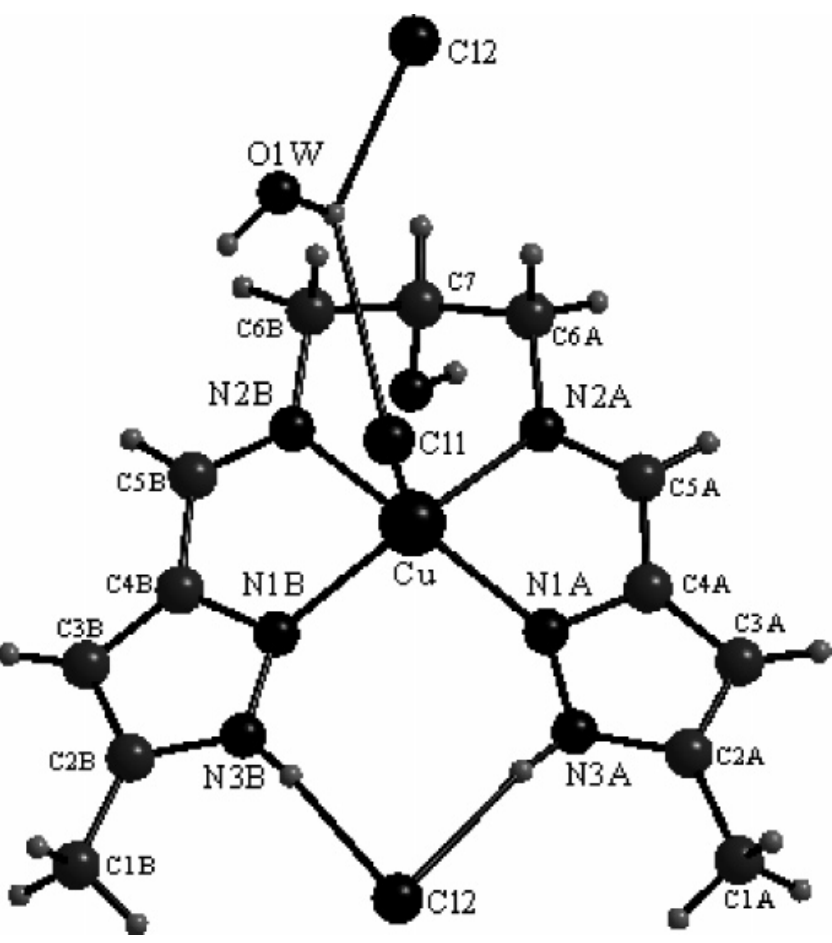

Figure 3. Molecular structure of $\mathbf{3}$.

and also participates in a weak H-bonding with uncoordinated lattice water molecule.

(c) Compound 5. A molecular view of the cationic portion of the complex is represented in Figure 4a. Selected metrical parameters are listed in Tables 1 and 2. The potentially tetradentate neutral ligand $\mathrm{H}_{2} \mathrm{~L}_{1}$ coordinates to the $\mathrm{Ni}(\mathrm{II})$ ion through the two iminic and two pyrazole nitrogen atoms. The coordination geometry of the nickel atom in the complex reveals a distorted octahedral geometry. Four short in-plane bonds $(2.060-2.082 \AA)$ are formed with the four nitrogen atoms $\mathrm{N}(2), \mathrm{N}(3), \mathrm{N}(4)$, and $\mathrm{N}(5)$ of the tetradentate Schiff base ligand. The geometry is completed by the oxygen atoms of the two coordinated water molecules in apical positions of the octahedron with longer distance $[\mathrm{Ni}-\mathrm{O}(2)=2.117 \AA$ and $\mathrm{Ni}-\mathrm{O}(3)=2.087 \AA]$. The shorter $\mathrm{Ni}-\mathrm{O}(3)$ bond distance than $\mathrm{Ni}-\mathrm{O}(2)$ suggests that the central $\mathrm{Ni}$ atom is slightly pulled toward the $\mathrm{O}(3)$ atom of water from the basal plane (mean plane deviation, $0.0132 \AA$ ) formed by the four nitrogen atoms of the ligand $\mathrm{H}_{2} \mathrm{~L}_{1}$. These $\mathrm{Ni}-\mathrm{N}$ distances are shorter than similar bonds reported for $\left[\mathrm{Ni}\left(\mathrm{MPz}_{3}\right.\right.$ tren $\left.)\right]\left(\mathrm{BF}_{4}\right)_{2}$. $0.5 \mathrm{H}_{2} \mathrm{O}^{7}$ (where $\mathrm{MPz}_{3}$ tren $=$ tris [4-(3-(5-methylpyrazole) 3-aza-3-butenyl]amine) and $\left[\mathrm{Ni}\left(\mathrm{H}_{3} \mathrm{~L}\right)\right]\left(\mathrm{NO}_{3}\right)_{2} \cdot \mathrm{MeOH}$ (where $\mathrm{H}_{3} \mathrm{~L}=\operatorname{tris}[2-(((2-$ phenylimidazol-4-yl)methylidene $)$ amino $)-$ ethyl]amine) and other complexes therein. ${ }^{19}$

$\mathrm{O}(1)$ of the ligand remains uncoordinated toward $\mathrm{Ni}(\mathrm{II})$ ion. Some benzene molecules are trapped into the symmetrical positions of the unit cell of the packing diagram during crystallization.

A network of weak H-bonding stabilizes the crystal structure. Two ionic perchlorates present per molecule form a H-bond symmetrically in various ways. One forms a $\mathrm{H}$-bond through one oxygen atom with both $\mathrm{N}-\mathrm{H}$ pyrazole,

(19) Katsuki, I.; Matsumoto, N.; Kojima, M. Inorg. Chem. 2000, 39, 3350.
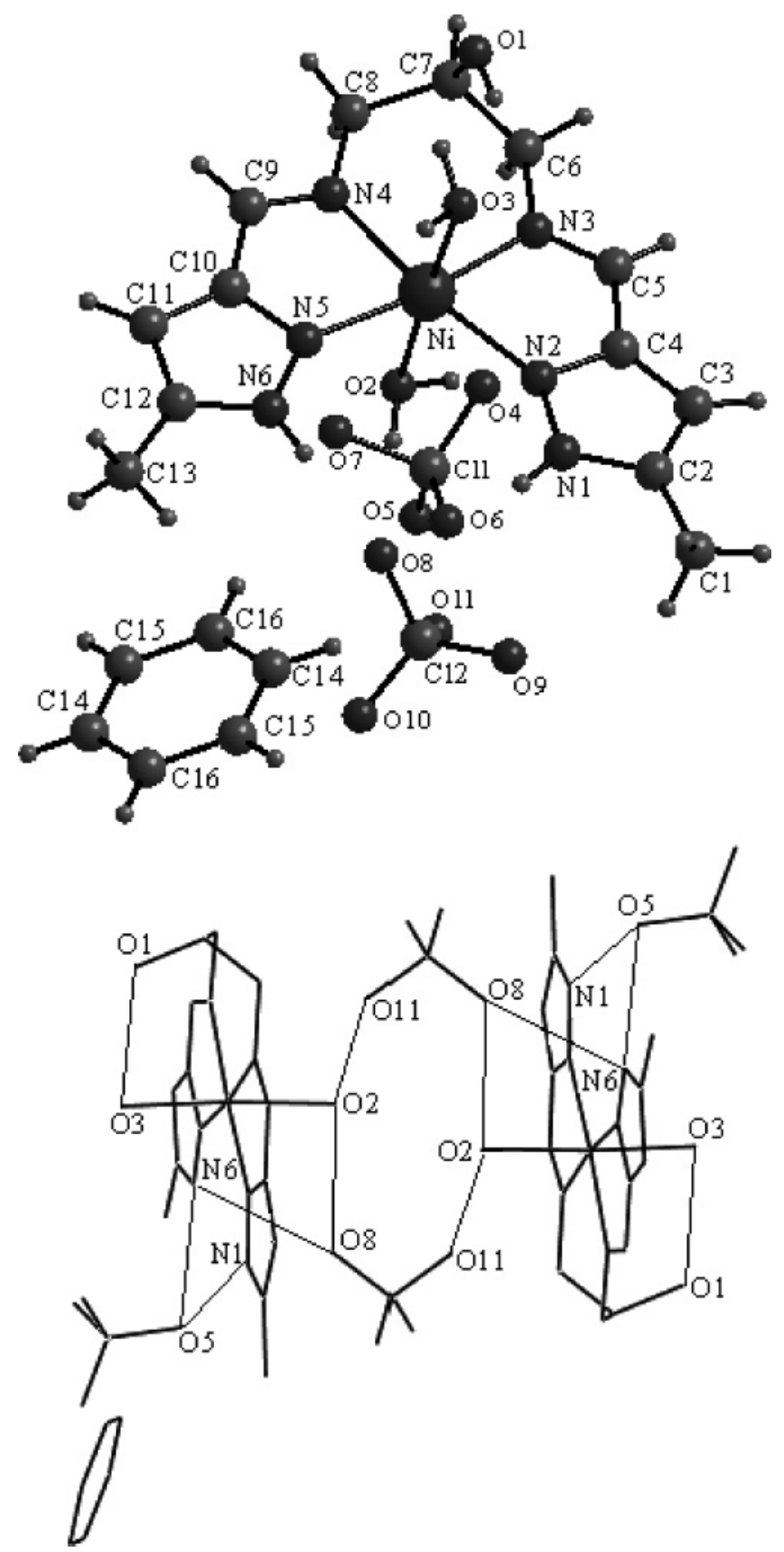

Figure 4. (a) Molecular structure of 5. (b) H-bonding mode of 5.

and the other one forms a bridge through two oxygen atoms with coordinated water of two complex molecules. Again one of the two oxygens of perchlorate forms a H-bond with $\mathrm{N}-\mathrm{H}$ pyrazole also. The second apical water molecule also forms a H-bond with uncoordinated $-\mathrm{OH}$ group.

Electronic Spectra and Conductance. The diffuse reflectance spectrum of the tetranuclear $\mathrm{Cu}$ complex exhibits only one broad band around $614 \mathrm{~nm}$, indicating the squarepyramidal geometry of the complex species. Similar observations with a little deviation in band position are also reported for the same chromophore $\mathrm{CuN}_{4} \mathrm{O}$ or $\mathrm{CuN}_{5} \cdot{ }^{15-17}$ The diffuse reflectance spectra of the mononuclear $\mathrm{Cu}$ complexes show only one broad band at $714 \mathrm{~nm}$ for chloro and $734 \mathrm{~nm}$ for bromo species. This red shift in band position from the tetranuclear $\mathrm{Cu}$ complex to mononuclear ones is due to the 

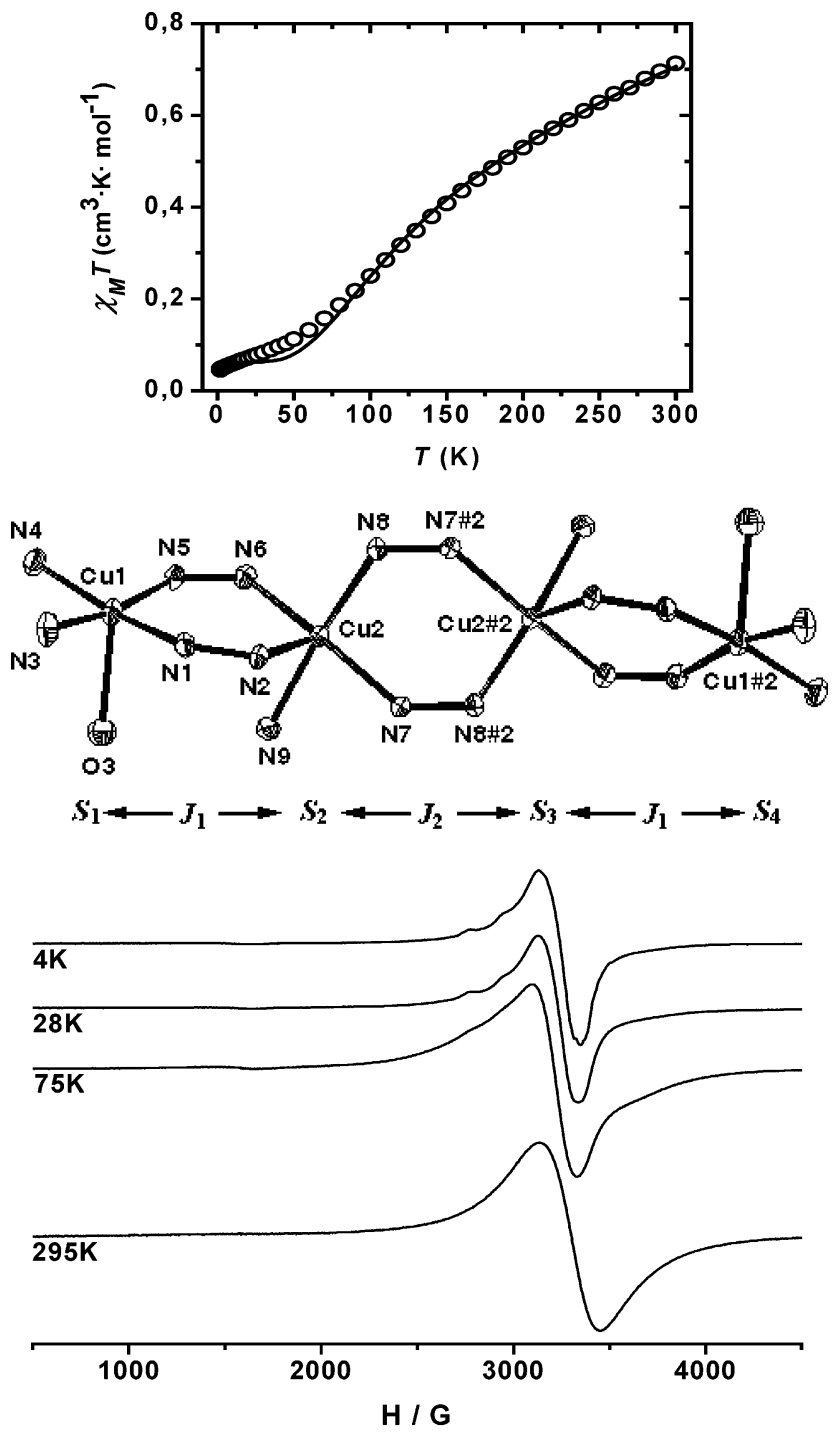

Figure 5. (a) Plot of $\chi_{\mathrm{M}} T$ product vs $T$ for compound 1 (molar value referred to four $\mathrm{Cu}$ atoms). Solid line corresponds to the best fit. (b) Figure 2 coupling scheme of $\mathbf{1}$. (c) Variable-temperature EPR of $\mathbf{1}$.

strong crystal field strength imposed by the negative donor ligands in the former species.

In DMF solution, the tetranuclear complex displays absorption bands at $616 \mathrm{~nm}\left(\epsilon=173 \mathrm{~L} \mathrm{M}^{-1} \mathrm{~cm}^{-1}\right)$. This corresponds to a d-d transition of $\mathrm{Cu}(\mathrm{II})$ in tetragonal field and is in accordance with those reported for polymetric complex $\left\{\left[\mathrm{CuL}^{4} \mathrm{Cl}\right]_{2}\left(\mathrm{ClO}_{4}\right)_{2}\right\}_{\infty},{ }^{20}$ and the spectral feature is typical for $\mathrm{Cu}(\mathrm{II})$ complexes with square pyramidal or distorted square pyramidal geometry, ${ }^{21}$ which generally exhibits a band in the 550-660 nm range $\left(\mathrm{d}_{x z}, \mathrm{~d}_{y z} \rightarrow \mathrm{d}_{x^{2}-y^{2}}\right) .{ }^{22}$ The band position of the tetranuclear $\mathrm{Cu}$ (II) complex remaining unchanged in solution indicates that no configurational change occurs on dissolution.

The electronic spectra of the reported mononuclear $\mathrm{Cu}-$ (II) complexes in DMF are characterized by a main broad

(20) Bu, X.-H.; Du, M.; Shang, Z.-L.; Zhang, R.-H.; Lio, D.-Z.; Shinoya, M.; Clifford, T. Inorg. Chem. 2000, 39, 4190.

(21) Lever, A. B. P. Inorganic Electronic Spectroscopy; Elsevier: New York, 1984; pp 560-570.

(22) Nielson, D. D.; Larsen, M. L.; Willett, R. D.; Legg, J. I. J. Am. Chem. Soc. 1971, 93, 5079. band at $684 \mathrm{~nm}\left(\epsilon=29 \mathrm{~L} \mathrm{M}^{-1} \mathrm{~cm}^{-1}\right)$ for chloro and 693 $\mathrm{nm}\left(\epsilon=122 \mathrm{~L} \mathrm{M}^{-1} \mathrm{~cm}^{-1}\right)$ for bromo species. This corresponds to a $\mathrm{d}-\mathrm{d}$ transition of $\mathrm{Cu}$ (II) in a weak tetragonal field and is in accordance with those reported compounds. ${ }^{8,15,17,23,24}$

The blue shift in optical spectra may be attributed to the solvent effect, which results in an increase in the energy gap between HOMO and LUMO. Probably the solvent stabilizes HOMO more effectively than LUMO.

The reflectance spectra of the Ni(II) complexes show three main bands in the region at 1025-1163 nm (for 5-9) [ $v_{1}$, ${ }^{3} \mathrm{~A}_{2 \mathrm{~g}} \rightarrow{ }^{3} \mathrm{~T}_{2 \mathrm{~g}}$ ], 742, $784 \mathrm{~nm}$ (for 5), 750, $791 \mathrm{~nm}$ (for 6), 747, $781 \mathrm{~nm}$ (for 7) 783, $829 \mathrm{~nm}$ (for 8) $\left[\nu_{2},{ }^{3} \mathrm{~A}_{2 \mathrm{~g}} \rightarrow{ }^{3} \mathrm{~T}_{1 \mathrm{~g}}(\mathrm{~F})\right]$, and 358-362 nm (for 5-9) $\left[v_{3},{ }^{3} \mathrm{~A}_{2 \mathrm{~g}} \rightarrow{ }^{3} \mathrm{~T}_{1 \mathrm{~g}}(\mathrm{P})\right]$, suggesting the octahedral geometry with the splitting of the middle band. ${ }^{25}$

The methanolic solution of each of five complexes shows two bands in the regions 1013-1059 $\left(v_{1}\right)$ and 743-752 nm $\left(v_{2}\right)$. This almost unalteration in band positions in the solution spectrum indicates that no configurational change occurs on dissolution.

The molar conductance data suggest the 1:1 and 1:2 electrolytic natures of the complexes $\mathbf{3}, \mathbf{4}, \mathbf{8}, 9$ and $\mathbf{1 , 5}, \mathbf{6}$, 7, respectively. The 1:2 electrolytic nature of $\mathbf{1}$ may be attributed to solvolysis of the same releasing coordinated $\mathrm{NO}_{3}$ groups as free anions, whereas the partial solvolysis of $\mathbf{8}$ and 9 explains their 1:1 electrolytic behavior.

Magnetic Study and EPR of 1. The variable-temperature magnetic susceptibility data for the compound $\mathbf{1}$ were recorded between 300 and $2 \mathrm{~K}$. A plot of $\chi_{\mathrm{M}} T$ vs $T$ is shown in Figure 5a. At $300 \mathrm{~K}$ it shows a $\chi_{\mathrm{M}} T$ value of $0.713 \mathrm{~cm}^{3}$ $\mathrm{mol}^{-1} \mathrm{~K}$ for the tetranuclear unit, smaller than that expected for four uncoupled $S=1 / 2$ ions with $g=2.0\left(1.5 \mathrm{~cm}^{3} \mathrm{~K}\right.$ $\left.\mathrm{mol}^{-1}\right)$. On cooling, $\chi_{\mathrm{M}} T$ decreases quickly, indicating a very strong AF coupling, reaching a value of $0.112 \mathrm{~cm}^{3} \mathrm{~K} \mathrm{~mol}^{-1}$ at $50 \mathrm{~K}$ and $0.045 \mathrm{~cm}^{3} \mathrm{~K} \mathrm{~mol}-1$ at $2 \mathrm{~K}$. The deviation observed at low temperature from the theoretical value that should correspond in this case $\left(\chi_{\mathrm{M}} T=0\right)$ may be due to the noncoupled $\mathrm{Cu}(\mathrm{II})$ ions in the polycrystalline powder sample.

Taking into account the topology of the complex, we count three exchange pathways in the compound, grouped into two averaged different exchange parameters, $J_{1}$ and $J_{2}$, as can observed in Figure 5b. The analysis of the experimental susceptibility data has been performed by the use of eq 1, where we take into account a proportion of a monomeric impurity $(\rho)$, for which the susceptibility is assumed to follow

$$
\chi_{\mathrm{M}}=(1-\rho) N g^{2} \beta^{2}\left(f(J, T) / K T+\rho N g^{2} \beta / K T\right.
$$

where

$$
\begin{gathered}
f(J, T)=\left[30 \exp \left(-E_{1} / k T\right)+6 \exp \left(-E_{2} / k T\right)+\right. \\
\left.6 \exp \left(-E_{3} / k T\right)+6 \exp \left(-E_{4} / k T\right)\right] / 5\left[\exp \left(-E_{1} / k T\right)+\right. \\
3 \exp \left(-E_{2} / k T\right)+3 \exp \left(-E_{3} / k T\right)+3 \exp \left(-E_{4} / k T\right)+ \\
\left.\exp \left(-E_{5} / k T\right)+\exp \left(-E_{6} / k T\right)\right]
\end{gathered}
$$

The $E_{n}$ values were obtained from the Hamiltonian 


$$
\begin{gathered}
H=-J_{1}\left(S_{1} \cdot S_{2}+S_{3} \cdot S_{4}\right)-J_{2} S_{2} \cdot S_{3} \\
E_{1}=-\left(J_{1} / 2\right)-\left(J_{2} / 4\right), \quad E_{2}=\left(J_{1} / 2\right)-\left(J_{2} / 4\right) \\
E_{3}=\left(J_{2} / 4\right)+\left[\left(J_{1}^{2}+J_{2}^{2}\right)^{1 / 2} / 2\right], \\
E_{4}=\left(J_{2} / 4\right)-\left[\left(J_{1}^{2}+J_{2}^{2}\right)^{1 / 2} / 2\right] \\
E_{5}=\left(J_{1} / 2\right)+\left(J_{2} / 4\right)+\left[\left(4 J_{1}^{2}-2 J_{1} J_{2}+J_{2}^{2}\right)^{1 / 2} / 2\right] \\
E_{6}=\left(J_{1} / 2\right)+\left(J_{2} / 4\right)-\left[\left(4 J_{1}^{2}-2 J_{1} J_{2}+J_{2}^{2}\right)^{1 / 2} / 2\right]
\end{gathered}
$$

The best fit parameters found are $J_{1}=-305.3 \mathrm{~cm}^{-1}, J_{2}=$ $-400.7 \mathrm{~cm}^{-1}, g=2.09$, and $\rho=0.0114$ with an error $R=$ $1.6 \times 10^{-4}$, where $R=\Sigma\left[\left(\chi_{\mathrm{M}}\right)_{\exp }-\left(\chi_{\mathrm{M}}\right)_{\text {cal }}\right]^{2} / \Sigma\left(\chi_{\mathrm{M}}\right)_{\exp }{ }^{2}$.

The calculated exchange constants take values close to those found in systems with similar bridging ligands, such as polyfunctional pyrazole complexes. ${ }^{26-32}$ The propagation of the magnetic superexchange via diazine $(\mathrm{N}-\mathrm{N})$ bridging ligand in the polyfunctional pyrazole, triazol, pyridazine, and phthalazine complexes ${ }^{26-44}$ is well-known and was correlated to the nature of the heterocyclic ring and the extent of doublebond character in the $\mathrm{N}-\mathrm{N}$ bond. Generally these ligands provide moderate to strong antiferromagnetic coupling depending on the nature of the diazine $\mathrm{N}-\mathrm{N}$ ligand.

The magnitude of the interaction between $\mathrm{Cu}(1) \cdots \mathrm{Cu}(2)$ and between $\mathrm{Cu}(2) \cdots \mathrm{Cu}(2) \# 2$ is reasonable for a short

(23) Lu, Q.; Shen, C.-Y.; Luo, Q.-H. Polyhedron 1993, 12, 2005.

(24) Luo, Q.; Lu, Q.; Dai, A.; Huang, L. J. Inorg. Biochem. 1993, 51, 655.

(25) Lee, J. D. Concise Inorganic Chemistry, 5th ed.; ELBS: 1996, p 960.

(26) Kamiusuki, T.; Okawa, H.; Matsumoto, N.; Kida, S. J. Chem. Soc., Dalton Trans. 1990, 195.

(27) Bayon, J. C.; Esteban, P.; Net, G.; Rasmussen, P. G.; Baker, K. N.; Hahn, C. W.; Gumz, M. M. Inorg. Chem. 1991, 30, 2572.

(28) Pons, J.; Lopez, X.; Casabo, J.; Teixidor, F.; Caubet, A.; Ruis, J.; Miravitlles, C. Inorg. Chim. Acta 1992, 195, 61.

(29) Steel, J. P. Coord. Chem. Rev. 1990, 106, 227.

(30) Bode, R. H.; Bol, J. E.; Driessen, W. L.; Hulsbergen, F. B.; Reedijk, J.; Spek, A. L. Inorg. Chem. 1999, 38, 1239, and references therein.

(31) Martens, C. F.; Schenning, A. P. H. J.; Feiters, M. C.; Berens, H. W.; van der Linden, J. G. M.; Admiraal, G.; Beurskens, P. T.; Kooijman, H.; Spek, A. L.; Nolte, R. J. M. Inorg. Chem. 1995, 34, 4735, and references therein.

(32) Komatsuzaki, H.; Ichikawa, S.; Hikichi, S.; Akita, M.; Moro-oka, Y. Inorg. Chem. 1998, 37, 3652.

(33) Bencini, A.; Gatteschi, D.; Zanchini, C.; Haasnoot, J. G.; Prins, R.; Reedijk, J. Inorg. Chem. 1985, 24, 2812.

(34) Koomen-van Oudenniel, W. M. E.; de Graff, R. A. G.; Haasnoot, J. G.; Prins, R.; Reedijk, J. Inorg. Chem. 1989, 28, 1128.

(35) van Koningsbruggen, P. J.; Gatteschi, D.; de Graff, R. A. G.; Haasnoot, J. G.; Reedijk, J.; Zanchini, C. Inorg. Chem. 1995, 34, 5175.

(36) Prins, R.; Birker, P. J. M. W. L.; Haasnoot, J. G.; Verschoor, G. C.; Reedijk, J. Inorg. Chem. 1985, 24, 4128.

(37) Slangen, P. M.; van Koningsbruggen, P. J.; Haasnoot, J. G.; Jansen, J.; Gorter, S.; Reedijk, J.; Kooijman, H.; Smeets, W. J. J.; Spek, A. L. Inorg. Chim. Acta 1993, 212, 289.

(38) Abraham, F.; Lagrenee, M.; Sueur, S.; Mernari, B.; Bremard, C. J. Chem. Soc., Dalton Trans. 1991, 1443.

(39) Mandal, S. K.; Thompson, L. K.; Newlands, M. J.; Lee, F. L.; LePage, Y.; Charland, J.-P.; Gabe, E. J. Inorg. Chim. Acta 1986, 122, 199.

(40) Thompson, L. K.; Mandal, S. K.; Charland, J.-P.; Gabe, E. J. Can. J. Chem. 1988, 66, 348.

(41) Tandon, S. S.; Thompson, L. K.; Hynes, R. C. Inorg. Chem. 1992, 31, 2210.

(42) Chen, L.; Thompson, L. K.; Bridson, J. N. Inorg. Chem. 1993, 32, 2938.

(43) Thompson, L. K.; Tandon, S. S.; Manuel, M. E. Inorg. Chem. 1995, 34, 2356.

(44) Tandon, S. S.; Thompson, L. K.; Manuel, M. E.; Bridson, J. N. Inorg. Chem. 1994, 33, 5555. exchange pathway that involves the two atoms $(\mathrm{N}-\mathrm{N})$. The difference in the values of the magnetic coupling $J_{1}$ and $J_{2}$ can be explained easily in terms of the magnetic orbital at each copper atom. $\mathrm{Cu}(2)$ and $\mathrm{Cu}(2) \# 2$ atoms are linked in the equatorial-equatorial coordination (short-short distances) by doubly $N^{1}, N^{2}$-bridging polyfunctional pyrazole ligands. In this situation, the magnetic exchange is propagated via the $\mathrm{d}_{x^{2}-y^{2}}$ orbitals on the $\mathrm{Cu}$ (II) ions which interact with the $\sigma$ orbitals of the nitrogen atoms of the bridging ligand leading, thus, a large antiferromagnetic contribution. The magnetic orbitals of the atoms $\mathrm{Cu}(2)$ and $\mathrm{Cu}(1)$ are linked both in equatorial-axial coordination (short-long) and equatorial-equatorial coordination (short-short). Considering a small admixture of the $\mathrm{d}_{x^{2}-y^{2}}$ and $\mathrm{d}_{z^{2}}$ orbitals, good overlapping occurs on only one side of the doubly $\mathrm{N}-\mathrm{N}$ bridge. The magnitude of the coupling $J_{1}$ is expected to be lower than that of $J_{2}$ as observed.

EPR spectra recorded on a powdered sample of the compound at $295 \mathrm{~K}$ shows an isotropic intense signal which corresponds to the transition $\Delta M_{\mathrm{S}}= \pm 1$, located at $g=2.120$ $(3302.4 \mathrm{G}$ for $v=9.7866 \mathrm{GHz})$ with a peak-to-peak line width $\Delta B_{\mathrm{pp}}$ of $316.7 \mathrm{G}$. When lowering the temperature from 295 up to $75 \mathrm{~K}$, the signal is narrowed slightly $\left(\Delta B_{\mathrm{pp}}\right.$ becomes 233.1) and a half-field signal can be distinguished at $g=4.479(1534.07 \mathrm{G}$ for $v=9.4517 \mathrm{GHz})$, which is associated with the $\Delta M_{\mathrm{S}}= \pm 2$ forbidden transition.

On the other hand, great care must be taken with the spectra at low temperature, because, due to the calculated $J$ values, the ground state $S=0$ will be the only one populated at 28 or $4 \mathrm{~K}$. Thus, the sample should be EPR-silent at these temperatures. The EPR signals are due, thus, to monomeric impurities, as already commented on in Magnetic Study and EPR of 1. The anisotropy and hyperfine coupling, typical of the $\mathrm{Cu}$ (II) mononuclear species, are clearly seen in the spectra.

RT EPR of 3 and 4. The EPR spectra for both copper complexes have been recorded in polycrystalline state at room temperature. The value of $g_{11}>g_{\perp}$ is well in consistent with a primarily $\mathrm{d}_{x^{2}-y^{2}}$ based ground state. ${ }^{45}$

The X-band EPR spectrum of the representative complex 3 has been recorded in frozen solution (in $\mathrm{MeOH} / \mathrm{EtOH}$ glass) at $77 \mathrm{~K}$ (X-band frequency). It is well-known that the EPR spectral pattern for square-pyramidal complexes of $\mathrm{Cu}$ (II) $\left(\mathrm{d}_{x^{2}-y^{2}}\right.$ ground states $\left.(\mathrm{gs})\right)$ is quite different from that observed for TBP $\left(\mathrm{d}_{z}{ }^{2}\right.$, gs). In general, frozen solution EPR spectra of square-pyramidal complexes are characterized by an axial pattern with the features $g_{\|}>2.1>g_{\perp}>2.0$ and $A \| l=(120-150) \times 10^{-4} \mathrm{~cm}^{-1},{ }^{46-50}$ whereas complexes with the TBP structure typically show EPR spectra having a "reversed axial" appearance with $g_{\perp}>g_{\|} \approx 2.0$ and $A_{\|}=$ $(60-100) \times 10^{-4} \mathrm{~cm}^{-1} \cdot{ }^{46-50}$

Thus, the coordination geometry around the central metal ion in the $\mathrm{Cu}$ complex can be deduced from an examination of the EPR spectral features. The spin Hamiltonian parameters $g_{\|}(2.14)>2.1>g_{\perp}>(2.05)>2.0$ and $A_{\|}=175 \times$ $10^{-4} \mathrm{~cm}^{-1}$ (within the limits of experimental error) are typical of a square-pyramidal geometry ${ }^{6,15}$ in solution. Here, the $G$

(45) El-Shazly, M. F.; Retaat, L. S. Trans. Met. Chem. 1981, 6, 10.

3888 Inorganic Chemistry, Vol. 44, No. 11, 2005 

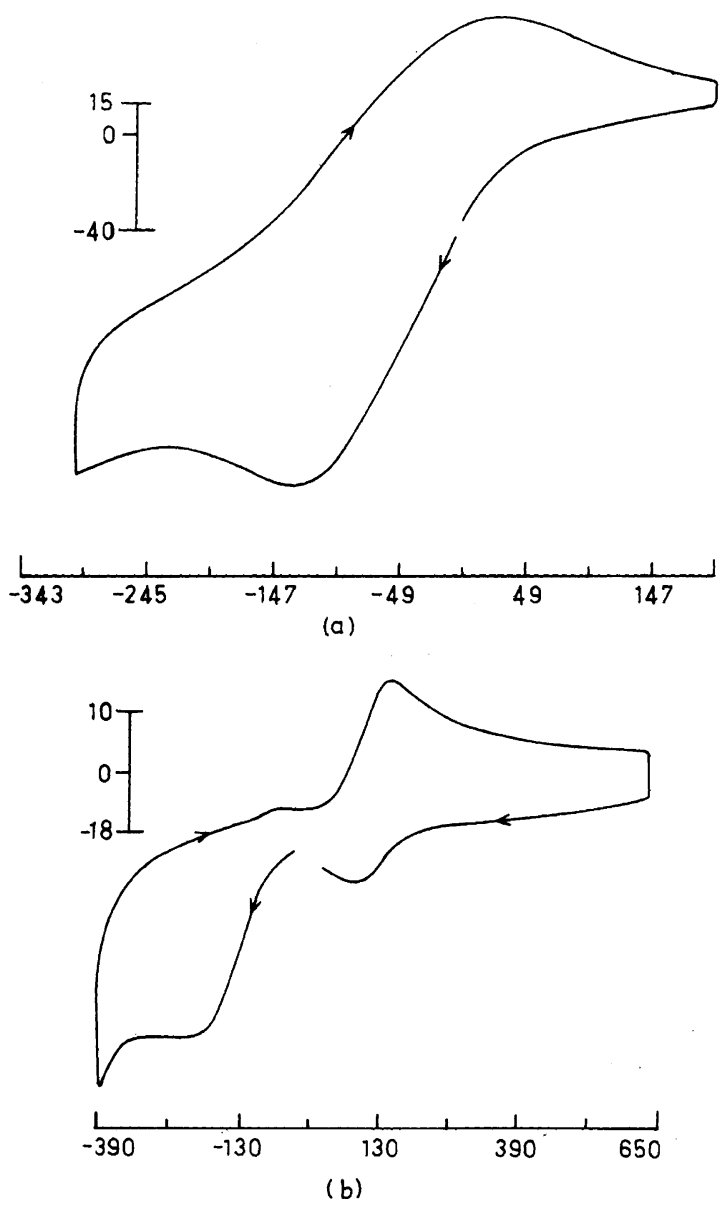

Figure 6. Cyclic voltammograms of (a) 3 and (b) 1 . This was recorded with a scan rate $100 \mathrm{mV} \mathrm{s}^{-1}$. All potentials are given vs SCE. All measurements have been carried out in TEAP/MeOH at $293 \mathrm{~K}$.

value of 2.8 indicates a $\mathrm{d}_{x^{2}-y^{2}}$ ground state having a weak exchange coupling which may be propagated through $\mathrm{H}$ bonds. $^{51,52}$

Electrochemistry. The cyclic voltammogram of complex 3 (Figure 6a) was measured in methanol over +0.20 to -0.30 $\mathrm{V}$. The complex displays a redox process of one electron transfer with Epc $=-0.124 \mathrm{~V}$, Epa $=0.032 \mathrm{~V}, \Delta \mathrm{Ep}=0.156$ $\mathrm{V}$, and $E_{1 / 2}=-0.048 \mathrm{~V}$ vs SCE. The reduction process corresponds to an irreversible $\mathrm{Cu}(\mathrm{II} / \mathrm{I})$ couple. The $E_{1 / 2}$ value is more positive than those of earlier reported Schiff base complexes $[\mathrm{Cu}(\mathrm{appn})]\left(\mathrm{ClO}_{4}\right)_{2}{ }^{23}$ (reduction potential, -0.472 $\mathrm{V}),[\mathrm{Cu}(\mathrm{bppn})]\left(\mathrm{ClO}_{4}\right)_{2} \cdot \mathrm{H}_{2} \mathrm{O}^{17}$ (reduction potential, -0.360 V) and a complex of Karlin $(-0.08 \mathrm{~V}) .^{53}$ and the higher positive value is due to the more $\pi$-acidity of the pyrazole moiety.

(46) Addison, A. W.; Hendriks, H. M. J.; Reedijk, J.; Thompson, L. K. Inorg. Chem. 1981, 20, 103.

(47) Duggan, M.; Ray, N.; Hathaway, B.; Tomilson, G.; Briant, P.; Plien, K. J. Chem. Soc., Dalton Trans. 1980, 1342.

(48) Nishida, Y.; Oishi, N.; Kida, S. Inorg. Chim. Acta 1980, 44, L257.

(49) Takahashi, K.; Ogawa, E.; Oishi, N.; Kida, S. Inorg. Chim. Acta 1982, 66, 97.

(50) Marpurgo, L.; Falcioni, R.; Rotildo, G.; Desideri, A.; Mondovi, B. Inorg. Chim. Acta, 1978, 28, L141.

(51) Jain, S. K.; Garg, B. S.; Bhoon, Y. K.; Klayman, D. L.; Scovill, J. P. Spectrochim. Acta 1985, 41A, 407.

(52) Bew, M. J.; Hathaway, B. J.; Faraday, R. J. J. Chem. Soc., Dalton Trans. 1972, 1229.

(53) Karlin, K. D.; Gultneh, Y.; Hutchinson, J. P.; Zubieta, J. J. Am. Chem. Soc. 1982, 104, 5240.
The electrochemical behavior of the tetranuclear copper complex (1; Figure 6b) in methanol shows two one-electron reduction and oxidation steps at different potentials in the range -0.40 to $+0.65 \mathrm{~V}$ vs SCE. It shows one reversible couple at $+0.14 \mathrm{~V}$ vs SCE $(\mathrm{Epc}=0.105 \mathrm{~V} ; \mathrm{Epa}=0.176 \mathrm{~V}$ $\Delta \mathrm{Ep}=0.071 \mathrm{~V} ; E_{1 / 2}=0.140 \mathrm{~V}$; the ratio $i_{\mathrm{pc}} / i_{\mathrm{pa}}$ is almost one), assigned to one electron-transfer process $\mathrm{Cu}^{\mathrm{II}}(1) \mathrm{Cu}^{\mathrm{II}}$ $(2) \rightarrow \mathrm{Cu}^{\mathrm{II}}(1) \mathrm{Cu}^{\mathrm{I}}(2) \cdot{ }^{54}$ The second irreversible couple around $-0.136 \mathrm{~V}$ vs SCE $(\mathrm{Epc}=-0.206 \mathrm{~V}$; Epa $=-0.065 \mathrm{~V}$; $\left.\Delta \mathrm{Ep}=0.141 \mathrm{~V} ; E_{1 / 2}=-0.136 \mathrm{~V}\right)$, assigned to $\mathrm{Cu}^{\mathrm{II}}(1) \mathrm{Cu}^{\mathrm{I}}-$ $(2) \rightarrow \mathrm{Cu}^{\mathrm{I}}(1) \mathrm{Cu}^{\mathrm{I}}(2)$, is obtained with very small response in the oxidation peak. The value of the cathodic current is larger than the anodic current, showing that the complexes undergo a chemical change after reduction. ${ }^{55}$

We think the $\mathrm{Cu}(2)$ center of the tetranuclear complex gives the reversible redox couple since it is coordinated by four pyrazole ring nitrogen atoms (two of which are pyrazolide $\mathrm{N}$-atoms having better $\pi$-acidity) than the $\mathrm{Cu}(1)$ center, where only two pyrazole ring nitrogen atoms are the donor sites. The above mononuclear copper complex which has nearly the same environment analogous to the $\mathrm{Cu}(1)$ center also shows the same type of redox couple.

\section{Summary}

The following are the principal findings and conclusions of the present study. Especially for the plasticity of the copper(II) geometry, such types of unusual observations are obtained. For a copper(II) metal center, the formation of products is highly anion-dependent. Using aldehyde and ammine (2:1 equivalent) and 1 equiv of copper(II) salt in the presence of $\mathrm{Cl}^{-}$and $\mathrm{Br}^{-}$, the desired Schiff base complexes are isolated, whereas in the presence of $\mathrm{ClO}_{4}{ }^{-}$, $\mathrm{BF}_{4}{ }^{-}$, and $\mathrm{NO}_{3}{ }^{-}$, the complexes of unusual macrocycles are formed via aldol type condensation involving four pyrazole aldehyde units. Here 1,3-DAP acts as a base for macrocycle formation but serves as the usual amine for Schiff base formation. For nickel, usual Schiff base complexes are isolated, which is anion-independent. Furthermore, using aldehyde and amine (2:2 equivalent) in the presence of 1 equiv of $\mathrm{Cu}\left(\mathrm{NO}_{3}\right)_{2} \cdot 6 \mathrm{H}_{2} \mathrm{O}$, a tetranuclear pyrazole bridged mixed ligand complex is obtained. Here, the mono Schiff base undergoes cyclization during complexation to form hydroxyhexhydropyrimidylpyrazole unit. The similar reaction when carried out with nickel(II) salts leads to a hygroscopic intractable material.

Acknowledgment. Financial support from the Council of Scientific and Industrial Research (CSIR), New Delhi, is gratefully acknowledged. A.H. thanks CSIR for the award of a Junior Research Fellowship. We are thankful to Prof. K. Nag, IACS, Kolkata, for many useful discussions and also to Prof. P. K. Bharadwaj, IIT Kanpur, for permitting us to use the Diamond program.

Supporting Information Available: Additional information in CIF format. This material is available free of charge via the Internet at http://pubs.acs.org.

\section{IC0501420}

(54) Neves, A.; Rossi, L. M.; Bortoluzzi, A. J.; Mangrich, A. S.; Haase, W.; Werner,R. J. Braz. Chem. Soc. 2001, 12, 747.

(55) Sujata, S.; Rajendiran, T. M.; Kannappan, R.; Venkatesan, R.; Rao, P. S. Proc. Indian Acad. Sci. (Chem. Sci.) 2000, 112, 559. 